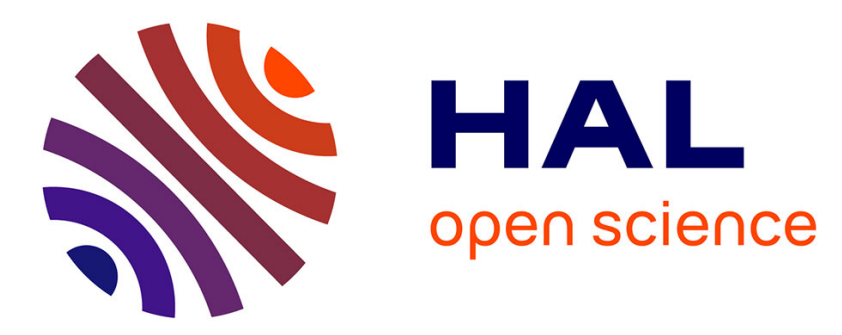

\title{
Dimethylated sulfur compounds in symbiotic protists: A potentially significant source for marine $\operatorname{DMS}(\mathrm{P})$
}

Andres Gutierrez-Rodriguez, Loic Pillet, Tristan Biard, Ward Said-Ahmad, Alon Amrani, Rafel Simó, Fabrice Not

\section{- To cite this version:}

Andres Gutierrez-Rodriguez, Loic Pillet, Tristan Biard, Ward Said-Ahmad, Alon Amrani, et al.. Dimethylated sulfur compounds in symbiotic protists: A potentially significant source for marine DMS(P). Limnology and Oceanography, 2017, 62 (3 ), pp.1139-1154 10.1002/lno.10491 . hal01480231

\section{HAL Id: hal-01480231 \\ https://hal.sorbonne-universite.fr/hal-01480231}

Submitted on 1 Mar 2017

HAL is a multi-disciplinary open access archive for the deposit and dissemination of scientific research documents, whether they are published or not. The documents may come from teaching and research institutions in France or abroad, or from public or private research centers.
L'archive ouverte pluridisciplinaire HAL, est destinée au dépôt et à la diffusion de documents scientifiques de niveau recherche, publiés ou non, émanant des établissements d'enseignement et de recherche français ou étrangers, des laboratoires publics ou privés. 


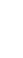

\section{DIMETHYLATED SULFUR COMPOUNDS IN SYMBIOTIC PROTISTS: A} POTENTIALLY SIGNIFICANT SOURCE FOR MARINE DMS(P)

Andres Gutierrez-Rodriguez ${ }^{1,4, *}$, Loic Pillet ${ }^{1,5}$, Tristan Biard ${ }^{1}$, Ward Said-Ahmad ${ }^{2}$, Alon Amrani ${ }^{2}$, Rafel Simó ${ }^{3}$ and Fabrice Not ${ }^{1}$

${ }^{1}$ Sorbonne Universités, UPMC Université Paris 06, CNRS, Laboratoire Adaptation et Diversité en Milieu Marin UMR7144, Station Biologique de Roscoff, 29680 Roscoff, France

${ }^{2}$ The Institute of Earth Sciences, The Hebrew University, Jerusalem 91904, Israel

${ }^{3}$ Department of Marine Biology and Oceanography, Institut de Ciencies del Mar (CSIC), Pg. Maritim de la Barceloneta 37-49,08003 Barcelona, Catalonia, Spain

${ }^{4}$ Current address: National Institute of Water and Atmospheric Research, Private Bag 14-901, Wellington 6241, New Zealand

${ }^{5}$ Current address: Department of Genetics and Evolution, University of Geneva, 30, qui Ernest-Ansermer, 1211 Geneva 11, Switzerland.

*Corresponding author email: Andres.gutierrez@,niwa.co.nz

Running head: Plankton symbiosis and DMS(P) cycling

Key words: Radiolaria, Symbiosis, DMS(P) 


\section{ABSTRACT}

Symbiosis with micro-algae (photosymbiosis) is a common feature among marine planktonic protists, but very little is known about the physiology and ecological significance of these associations. High concentrations of dimethylsulfoniopropionate (DMSP), a metabolite produced by marine microalgae, are commonly observed in coral-microalgae symbiosis, where $\mathrm{DMS}(\mathrm{P})$ is involved in multiple physiological functions. Knowledge on concentration and role of DMSP in analogous photosymbiosis in plankton is lacking. Here, we assess the total DMSP $(\mathrm{DMSP}=\mathrm{DMSP}+\mathrm{DMS})$ concentration and natural stable isotopes of sulfur across ecologically relevant symbiotic plankton groups, the Radiolaria and Foraminifera. We found that intracellular DMSPt concentrations in microalgal symbionts were among the highest recorded $\left(\right.$ range $\left.=170-702 \mathrm{mmol} \mathrm{L}^{-1}\right)$, while lower concentrations $\left(\right.$ range $\left.=0.1-23 \mathrm{mmol} \mathrm{L}^{-1}\right)$ were characteristic of the holobiont (i.e. host-microalgae). The contribution of symbiotic Radiolaria to the water column particulate DMSPt concentration ranged 0.1-8\%. Sulfur isotopic composition $\left({ }^{34} \mathrm{~S}\right)$ of DMSPt in the Collodaria holobionts was significantly higher than their symbiotic microalgae isolated in culture. Despite their high intracellular DMSPt content, $\mathrm{SO}_{4}{ }^{2-}$ uptake in these holobionts throughout 3-day incubations was not detected. We observed a systematic ${ }^{34}$ S depletion $(\sim 1.5 \%)$ of DMS relative to DMSP in experimental incubations containing filtered seawater, which we hypothesize is related to the bacterial preference for the uptake of ${ }^{34}$ S-depleted DMS. Overall, the results indicate that plankton symbiosis can, at times, represent a potentially important source of DMS(P). Specific differences in ${ }^{34} \mathrm{~S}$ provided new insights into sulfur isotopic fractionation associated with DMS(P) biotransformation processes, with potential implications for current interpretations of isotopically tracked biogenic sources of marine aerosols. 


\section{INTRODUCTION}

Dimethylsulfoniopropionate (DMSP) is a widespread metabolite in marine ecosystems, mainly produced by marine microalgae (Keller et al. 1989; Blunden et al. 1992; Raina et al. 2013). It is involved in multiple cross-scale processes, from cell physiology to ecosystem functioning. Physiologically, DMSP has been demonstrated to play an important role in osmotic acclimation (Vairavamurthy et al. 1985; Kirst 1990; Lyon et al. 2016) and cryoprotection in polar algae (Kirst et al. 1991; Karsten et al. 1996). DMSP production and breakdown have been also hypothesized to act as an overflow mechanism to get rid of excess reduced sulfur (Stefels 2000), to confer antioxidant protection by scavenging intracellular hydroxyl radical (Sunda et al. 2002; Bucciarelli et al. 2013; Deschaseaux et al. 2014), and to participate in the regulation of phytoplankton buoyancy through replacement of other organic solutes (Lavoie et al 2015, 2016). Beyond cellular limits, recent work suggests that DMSP and its cleavage product dimethylsulfide (DMS) act as efficient info-chemicals among plankton microorganisms (Seymour et al. 2010; Garces et al. 2013) and with higher trophic levels (Savoca and Nevitt 2014). DMS is a volatile compound that ventilates to the atmosphere and represents the main global biogenic source of atmospheric sulfur (Bates et al. 1992; Simó 2001). Several oxidation processes in the atmosphere transform DMS into sulfuric and methanesulfonic acids, which are key participants of cloud formation (Andreae 1997). Three decades after it was postulated, the hypothesis of a feedback loop between phytoplankton DMS production, cloud formation and climate regulation (Charlson et al. 1987), remains controversial. Issues like the relative contribution of DMS oxidation products, sea salt and organics to the number of cloud condensation nuclei are yet to be resolved (Quinn and Bates 2011; Lana et al. 2012). 
In addition to phytoplankton, heterotrophic organisms containing endosymbiotic microalgae (i.e. photosymbiotic holobionts) can be an important source of DMS(P) (Hill et al. 2000; Broadbent et al. 2002; Van Alstyne et al. 2006). Indeed, coral reefs hold the highest natural concentrations of oceanic DMS(P) reported to date (Broadbent and Jones 2004). The production of DMSP in corals is seemingly associated with the endosymbiotic dinoflagellate Symbiodinium sp. (Van Alstyne et al. 2009), although a recent study showed capacity for the juvenile animal hosts to produce DMSP as well (Raina et al. 2013). Less studied than that of corals, photosymbiosis is a common feature in the planktonic realm, particularly among protists belonging to the Rhizaria eukaryotic super-group (e.g. Foraminifera and Radiolaria) (Stoecker et al. 2009; Nowack and Melkonian 2010; Decelle et al. 2015). Radiolaria are amoeboid protists exhibiting mineral skeletons that are abundant and widespread in modern oceans (Anderson 1983; Stemmann et al. 2008; Not et al. 2009; Biard et al. 2016). They include five major groups - Collodaria, Nassellaria, Spumellaria, Taxopodia and Acantharia spanning a large size range, from a few micrometers for small solitary cells up to several centimeters for colonial forms of the Collodaria (Dennett et al. 2002; Caron et al. 2012; Suzuki and Not 2015), although the bulk of cell sizes range between 200-500 $\mu \mathrm{m}$ (Michaels 1988; Caron and Swanberg 1990). They are active predators, but many species dwelling in the surface layers harbor endosymbiotic microalgae in their cytoplasm, which allows them to thrive in ecological niches that otherwise would be less favorable (Decelle et al. 2015).

These symbiotic relationships involve essentially dinoflagellate microalgae such as Brandtodinium nutricula (Probert et al. 2014) and Gymnoxanthella radiolariae (Yuasa et al. 2016) in the case of Radiolaria, or Pelagodinium beii (Siano et al. 2010) in the case of Foraminifera. The Prymnesiophyceae species Phaeocystis sp., an abundant and widespread microalgal genus, has been recently described in symbiosis with acantharians (Decelle et al. 
2012). Both Dinophyceae and Prymnesiophyceae classes are typical major DMSP producers (Keller et al. 1989; Caruana and Malin 2014), and include keystone species for the biogeochemical sulfur and carbon cycles (Malin and Steinke 2004; Schoemann et al. 2005). Acantharia-Phaeocystis sp. holobionts exhibit extremely high DMSP cellular content, with values significantly higher than those expected if all DMSP was contained in the endosymbiotic microalgae (Decelle et al. 2012). Should elevated cellular content of DMSP be a common feature not only in benthic, but also in planktonic photosymbiosis, this widespread but traditionally overlooked functional group of plankton (i.e. photosymbiotic) may constitute a relevant source of biogenic DMS(P) previously unaccounted by the standard microplankton oriented (i.e. $<200 \mu \mathrm{m})$ sampling procedures.

The complexity of marine biogeochemistry makes it difficult to identify and assess the multiple biological sources and flows of DMS(P) from and through the different compartments of the pelagic ecosystem, and their links to the lower atmosphere (Simó, 2001). In this context, the sulfur isotope ratio $\left({ }^{34} \mathrm{~S} /{ }^{32} \mathrm{~S}\right.$; i.e. $\left.\delta^{34} \mathrm{~S}\right)$ in aerosol sulfate has been used to assess the contribution of different sources, mainly anthropogenic vs marine (Kaye 1987; Norman et al. 1999; Patris et al. 2002). Recent pioneering measurements in macroalgae and natural phytoplankton assemblages have provided similar $\delta^{34} \mathrm{~S}$ values for DMSP but have contradictory views of the isotopic fractionation associated with biotransformation processes in the formation of DMS (Oduro et al. 2012; Amrani et al. 2013). In natural planktonic systems, phytoplankton cells are often too small and too intermixed with other organisms to be isolated in sufficient quantities for analysis of sulfur isotopic composition of DMSP by conventional isotope ratio analysis methods. This hampers the characterization of the isotopic composition of specific phytoplankton taxa or even functional groups in the field, and little is known about the contribution of the different phytoplanktonic components to the bulk 
community isotopic composition of DMSP. The new method of Compound Specific Sulfur Isotope Analysis (CSSIA) enables sub-nanogram level sensitivity (Amrani et al. 2009; SaidAhmad and Amrani 2013) and opens the door for such single-cell level studies. The present study aims at opening this black box and refining our understanding of the different biogenic sources and transformations of dimethyl sulfur compounds in planktonic systems, with particular attention to the contribution of widespread photosymbiotic organisms. We have combined CSSIA with culture and field-based approaches for free-living phytoplankton and single-celled symbiotic Rhizaria (Radiolaria and Foraminifera) collected from different environments. The specific objectives of our study were to assess i) the cellular DMSP content, ii) the S-isotopic composition of DMSP and iii) the potential fractionation associated with DMSP biosynthesis and degradation to DMS in photosymbiotic Rhizaria and phytoplankton.

\section{METHODS}

Cultures of free-living microalgae and field sampling --- Monoclonal cultures of free-living strains of symbiotic dinoflagellates Brandtodinium nutricula (RCC3468) (Probert et al. 2014), Gymnoxanthella radiolariae (RCC3507) (Yuasa et al. 2016), and Pelagodinium beii (RCC1491) (Siano et al. 2010) have been previously obtained through single-cell isolation from their radiolarian and foraminiferan hosts, respectively. Cultures of Phaeocystis strain RCC1383, found in association with symbiotic Acantharia (Decelle et al. 2012), but originally isolated in its free-living stage, were chosen to represent the free-living symbiotic algae of the ubiquitous Acantharia-Phaeocystis symbiotic association. All cultures were maintained in $0.22 \mu \mathrm{m}$ filter-sterilized (Stericup-GP, Millipore) seawater with K/2 (-Tris,-Si) medium supplements (Keller et al. 1987) at $18^{\circ} \mathrm{C}, \sim 80 \mu \mathrm{mol}$ photon $\mathrm{m}^{-2} \mathrm{~s}^{-1}$ light intensity and 14:10 light:dark cycle in the lab. Samples for DMSP analysis, cell counts and image-based 
analysis of biovolume (see below) were taken for cultures at exponential and stationary phase, during night and daytime (4 hours into each cycle; Supplementary information).

Field samples of symbiotic Radiolaria and Foraminifera were collected in coastal waters of the Red Sea in Eilat $\left(29^{\circ} 33^{\prime} \mathrm{N}, 34^{\circ} 57^{\prime} \mathrm{E}\right)$ and the western Mediterranean in Villefranche-sur-Mer $\left(43^{\circ} 42^{\prime} \mathrm{N}, 7^{\circ} 18^{\prime} \mathrm{E}\right)$ during March and June of 2014, respectively. Plankton community was sampled using plankton net with $220 \mu \mathrm{m}$ mesh size towed obliquely (0-30 $\mathrm{m})$ for 10 minutes from a boat or swimming at surface $(0-5 \mathrm{~m})$ for approximately 200 m. Collected samples were immediately diluted in buckets with freshly collected surface seawater, protected from direct sunlight, and transported to the lab within less than an hour. Individual specimens were then manually sorted under a stereomicroscope using a micropipette and transferred to Petri dishes in the case of single-celled acantharians and foraminiferans, and to larger beakers in the case of collodarians, where they were rinsed with surface $0.22 \mu \mathrm{m}$ filtered seawater (fsw) before following DMSP/image analysis or experimental procedure. This single-cell approach allowed us to assess intracellular DMSP concentration and isotopic composition $\left(\delta^{34} \mathrm{~S}-\mathrm{DMSP}\right)$ in ecologically relevant, uncultured specific symbiotic taxa. While large collodarians could be identified to genus level based on morphological characteristics, identification was not so reliable for Acantharia, and so related morphotypes of different species were used in subsequent measurements (Fig. 1). Samples manipulation and experimental work was conducted in the laboratory facilities of the Interuniversity Institute for Marine Sciences in Eilat (Israel) and the Observatoire Oceanologique de Villefranche-sur-Mer (France).

\section{Image analysis and cellular biovolume assessment and microalgae cell counts ---}

Cultured and uncultured organisms were imaged using a digital camera (Canon EOS 5D) coupled to an optical direct microscope (Olympus BX51 and Nikon Eclipse) or stereoscope 
(Zeiss Stereo discovery V200). Microalgae and rhizarian cell and colonial size dimensions were assessed with the ImageJ open source image processing software (https://imagej.nih.gov/ij/) and organismal biovolume derived from minimum and maximum length dimensions and the formula of a prolate sphere, as described in Biard et al. (2016). For single-celled amoeboid acantharians and Foraminifera with highly variable space occupation of the cytoplasm the perimeter drawn to estimate the $\min / \max$ lengths included the skeleton axis regardless of the position of the cytoplasm; while for colonial collodarians, the perimeter was given by the contour of the colony. Samples of cultured phytoplankton were fixed with $0.1 \%$ glutaraldehyde (final concentration), for $15 \mathrm{~min}$ at room temperature in the dark, flashfreeze in liquid nitrogen and stored at $-80{ }^{\circ} \mathrm{C}$ (Marie et al. 1997) until analysis. Cell abundance was determined using a FACSAria (Becton Dickinson, San José, CA, USA) Flow Cytometer and raw files analyzed with the FlowJo software (TreeStar Data Analysis Software).

Dimethyl sulfur compounds concentration analysis --- DMSP was measured as the DMS evolved by alkaline hydrolysis using purge and trap coupled to gas chromatography (Shimadzu GC14A) with flame photometric detection (FPD) as described in Galí et al. (2011). We therefore measured total DMSP (hereafter DMSPt) that comprises mainly particulate DMSP+DMS in the case of individual symbiotic specimens, while DMSPt measurements in cultured microalgae comprise both particulate and dissolved forms. For cultured phytoplankton DMSP analysis, an aliquot of 0.5-1 mL from the culture was dispensed into $13 \mathrm{~mL}$ gas-tight vials previously filled with MilliQ water. For single-celled Radiolaria and Foraminifera, 2-4 specimens were transferred from the containers where they had been rinsed with fsw, to a $13 \mathrm{~mL}$ vial previously filled with MilliQ. For colonial Radiolaria, 1-2 specimens were transferred to the analytical vial, which was filled with fsw 
instead, to minimize the potential contamination by DMSO in the MilliQ water system. We then added two pellets of $\mathrm{NaOH}$ before sealing the vial with Teflon-capped lids. Samples were stored at room temperature in the dark until analysis, within the next 2 months. To account for dissolved DMSPt in solution, we preserved and analyzed blanks of the solutions where the organisms were analyzed (MilliQ for microalgae and single-celled

Radiolaria/Foraminifera, and fsw for colonial Radiolaria). Dissolved DMSP measured in the blanks was then subtracted from total DMSP in the corresponding organism samples to yield the particulate total DMSP values presented in this study. The contribution of dissolved DMSP to the total DMSP was minor $(<5 \%)$.

Samples were sparged with $40 \mathrm{~mL} \mathrm{~min}{ }^{-1}$ of high-purity helium, with the volatiles trapped in a Teflon loop tube submersed in liquid nitrogen for 3-5 min before re-volatizing them by placing the Teflon tube in hot water. Sulfur compounds were separated using a packed Carbopack ${ }^{\circledR} 60 / 80$ mesh column (Sigma-Aldrich) maintained at $170^{\circ} \mathrm{C}$. Intracellular content and cell concentration of cultured microalgae and freshly-collected Radiolaria or Foraminifera holobionts were assessed from the concentration of DMSPt measured in the sample vial minus the corresponding blank, and normalized by the number and biovolume of the specimens fixed in the vial. DMSP cell content in symbiotic microalgae within the holobiont - in hospite - were calculated by dividing the DMSPt measured for the holobiont by the mean number of host cells per colony surface, and also the mean number of microalgae cells per host obtained from image analysis, assuming that the DMSP measured in the holobiont was entirely confined in the symbionts.

\section{Analysis of sulfur isotopic composition of sulfate and dimethyl sulfur compounds ---}

The samples for sulfur isotope analysis of DMSP were prepared similarly to the concentration measurements and therefore, they refer to DMSPt as well. For sulfur isotopic composition of 
DMS, non-fixed samples were analyzed within 36 hours of collection (see below). Sulfur isotopic composition of DMS and cellular DMSP were measured by purge and trap system that was connected to a gas chromatograph (GC) coupled to a multicollector inductively coupled plasma mass spectrometer (MC-ICPMS) (Amrani et al. 2009; Said-Ahmad and Amrani 2013). Details for this method can be found in Said-Ahmad and Amrani (2013).

Briefly, seawater samples diluted in anoxic MilliQ or fsw were collected from the original $13 \mathrm{ml}$ vial using a syringe with minimal disturbance, and injected gently into a new $40 \mathrm{~mL}$ sparging vial equipped with a Teflon septum. The vial was then sparged with He $(40 \mathrm{~mL} / \mathrm{min})$ for 12 minutes. Water vapor was removed by a Nafion-membrane dryer (Perma pure LLC, NJ, USA) using dry $\mathrm{N}_{2}$ as the counter flow. A Teflon sample loop was inserted in a dewar of liquid $\mathrm{N}_{2}$ to trap DMS. After sparging, the 6-port valve (Valco Instrument Co, TX, USA; heated to $80^{\circ} \mathrm{C}$ ) was turned to the inject position, and the sample loop transferred quickly from the liquid $\mathrm{N}_{2}$ to hot water so that the trapped gases were injected into a Agilent J\&W capillary column (DB-1, 60m x $0.32 \mathrm{~mm}$ ID x $1.0 \mu \mathrm{m}$ ), connected directly to the 6-port valve. At the same time the GC (Perkin Elmer 580) and the MC-ICPMS (Neptune Plus, ThermoFischer Scientific) were started. A standard DMS sample was introduced to the system for calibration every 3-4 samples and we used a bracketing technique to correct for instrumental mass bias and calibration of the $\mathrm{SF}_{6}$ internal standard (Said-Ahmad and Amrani 2013). The results are expressed in conventional $\delta^{34} \mathrm{~S}$ notation as a per mil (\%o) deviation from the international standard V-CDT (Vienna Canyon Diablo Troilite) according to the equation below.

\section{$\left.{ }^{3} S^{4} R^{4} P_{r} R_{n}^{\top}\right)$}

where ${ }^{34} \mathrm{R}$ is the integrated ${ }^{34} \mathrm{~S} /{ }^{32} \mathrm{~S}$ ion-current ratio of the sample and standard peaks. Analytical precision of analysis of DMS and DMSP standards was usually in the range of 0.1 10 
0.4\% ( $1 \sigma$ standard deviation). The precision of sulfur isotope analysis for duplicate or triplicate samples of seawater and organism samples were usually less than $1 \%$. Accuracy as calculated by standards was in the range of $0.2 \%$ (Said-Ahmad and Amrani 2013) and estimated to be better than $1 \%$ or for the seawater samples.

Dissolved sulfate $\left(\mathrm{SO}_{4}{ }^{2-}\right)$ sulfur isotope analysis was performed by a conventional elemental analyzer (EA) coupled to isotope ratio mass spectrometer (IRMS) method (Giesemann et al. 1994) using Delta Plus (Thermo) IRMS. Samples of $\mathrm{BaSO}_{4}$ were prepared from diluted seawater samples by addition of $5 \% \mathrm{BaCl}_{2}$ solution and then analyzed for their $\delta^{34} \mathrm{~S}$ values by EA-IRMS. The sulfur isotope reference materials NBS-127 $\left(\mathrm{BaSO}_{4} ; \delta^{34} \mathrm{~S}=\right.$ 21.1\%o), IAEA-S-1 ( $\left.\mathrm{Ag}_{2} \mathrm{~S} ;-0.3 \%\right)$, and IAEA-SO-6 $\left(\mathrm{BaSO}_{4} ;-34.1 \%\right)$ were purchased from the National Institute of Standards and Technology (NIST) and used for calibration. Precision of this method for duplicates/triplicates was usually better than $0.3 \%$.

Sulfate assimilation and DMSP synthesis experiment --- For the biological sulfate assimilation experiment we incubated two cultured strains of microalgae

(Phaeocystis_RCC1383 and B.nutricula_RCC3468) and freshly-collected specimens of solitary symbiotic Thalasicolla sp. (Collodaria-Brandtodinium holobiont) during three days in two different types of $\mathrm{K} / 2$ culture media prepared with isotopically distinct sulfate (Fig. 2a). One media ('Heavy') was prepared with filtered seawater amended with standard K/2 supplements to yield an average seawater sulfate $\delta^{34} \mathrm{~S}$ of $21.5 \pm 0.5 \%$ at the beginning of the incubations. The second media ('Light') consisted of artificial seawater (Berges et al. 2001) prepared using isotopically depleted $\delta^{34}$ S-Sulfate relative to seawater sulfate, and mixed in $1: 1$ ratio with $\mathrm{K} / 2$ standard media, as described above, to give a sulfate $\delta^{34} \mathrm{~S}$ value of $7.6 \pm 0.4 \%$. This procedure resulted in two 2-L batches of media with very distinct $\delta^{34} \mathrm{~S}$-Sulfate composition but virtually identical nutrient concentrations. Experimental incubations for 11 
each microalgae species were prepared by inoculating a $50 \mathrm{~mL}$ aliquot from a culture that had been maintained in $\mathrm{K} / 2$-based standard media for at least 50 generations, into $1 \mathrm{~L}$ of 'Heavy' and 'Light' media. After gentle homogenization initial samples $\left(\mathrm{T}_{0}\right)$ were taken from the two cultures and the remaining volume was subsequently aliquoted into 8 replicated $70 \mathrm{~mL}$ sterile tissue culture vessels (Fig. 2a). For incubations of Radiolaria holobionts freshly-collected specimens, collected and maintained in $0.2 \mu \mathrm{m}$ fsw since the previous day, were transferred ( 2 ind/vessel) into 8 replicated tissue culture vessels previously filled with 'Heavy' or 'Light' media. Experimental design included therefore, three organismal types - two symbiotic microalgae strains in free-living stage, and one Radiolaria holobiont - each distributed on a series of replicated 8 vessels, half of which had been filled with 'Heavy' or 'Light' media, respectively (Fig. 2a). Organisms were incubated in parallel under constant temperature (19$\left.20^{\circ} \mathrm{C}\right)$ and light $\left(200 \mu \mathrm{mol}\right.$ photon $\mathrm{m}^{-2} \mathrm{~s}^{-1}, 14: 10$ light:dark cycle) conditions in the lab. Replicated incubations from each organism and media type were sampled at time 0 and after 22, 46 and 70 hours of incubations for analysis of DMSPt concentration and sulfur isotopic composition.

$D M S P \rightarrow D M S$ cleavage fractionation experiment --- To assess potential differences in the isotopic signature of the DMS generated by symbiotic Radiolaria from that of the microbial community we determined the sulfur isotope composition of DMS resulting from the cleavage of DMSP produced during experimental incubations containing different planktonic biota (Fig. 2b). This was achieved by incubating a) the natural microbial assemblage $<200 \mu \mathrm{m}$ (i.e. surface whole sea water, $(w s w)$ ), b) a heterogeneous assemblage of Acantharia-microalgae holobionts (100 ind.) in $0.2 \mu \mathrm{m}$-filtered seawater obtained with sterile Stericup filtration device (Stericup-GP, Millipore) (fsw + rads), and a third control treatment containing only the same filtered seawater ( $f$ sw-only) (Fig. 2 b). Organisms were manipulated 
using sterile micropipette and petri dishes on the laboratory bench and incubations were prepared in $70 \mathrm{~mL}$ sterile polystyrene tissue culture vessels. Triplicates of each assemblage type were incubated for 4 hours (13:30-17:30) under 30\% incident light. Samples from wsw for DMSP were preserved with $\mathrm{NaOH}$ in gas-tight vials, while those for DMS were maintained in the dark at similar temperature to that of the surface water, until analysis. In the " $f_{s w}+$ rads" treatments, 5 individuals from each incubation were sorted, imaged and preserved for DMSP concentration. The remaining $\sim 95$ specimens were transferred into $40 \mathrm{~mL}$ gas-tight vials with the same fsw where they were incubated and kept at room temperature until analysis.

Statistical analysis --- The statistical significance of the difference between organism groups in DMSP cell content, DMSP and DMS sulfur isotopic composition was tested with one-way ANOVA followed by Tukey’s post hoc test. All statistical analyses were conducted on experimental results using GraphPad 5.0 software (GraphPad Software, Inc, La Jolla, USA).

\section{RESULTS}

Intracellular DMSPt in cultured phytoplankton and freshly collected photosymbiotic organisms --- Table 1 summarizes cell size, intracellular DMSPt content and concentration in cultures of free-living phytoplankton and field-collected symbiotic Radiolaria and Foraminifera holobionts (Fig. 1). The highest values were observed in the large CollodariaBrandtodinium holobiont with average DMSPt cellular content ranging from $2757 \pm 750$ to $3652 \pm 2008$ pmol specimen $^{-1}$ (Table 1). Colonial forms contained hundreds of radiolarian cells (i.e., estimated by the number of central capsules forming the colonies) per specimen $\left(\mathrm{N}_{\text {Sphaerozoum }}=166 \pm 65 ; \mathrm{N}_{\text {Collozoum }}=509 \pm 72\right.$ central capsules colony $\left.{ }^{-1}\right)$. Each central capsule harbored a few endosymbiont cells $\left(\mathrm{N}_{\text {Collozoum }}=9.8 \pm 3.5, \mathrm{~N}_{\text {Sphaerozoum }}=9.1 \pm 2.6\right.$ symbionts 13 
central capsule $\left.^{-1}\right)$. Solitary forms, consisting of millimeters-size single host cell, contained hundreds of endosymbiotic cells $\left(\mathrm{N}_{\text {Thalassicolla }}=723 \pm 703\right.$ symbionts radiolarian cell $\left.{ }^{-1}\right)$ (Fig. 1 , Table 1). DMSPt content in different morphotypes of single-celled Acantharia and planktonic Foraminifera were much lower, according to their lower cell size, and varied within a relatively narrow range (15-38 $\left.\mathrm{pmol} \mathrm{cell}^{-1}\right)$. Foraminifera $\left(37.8 \pm 15.5 \mathrm{pmol} \mathrm{cell}^{-1}\right)$ and 'Star' morphotype acantharians $\left(36.4 \pm 10.4 \mathrm{pmol} \mathrm{cell}^{-1}\right)$ exhibited higher values than $A$. elongata $\left(15.2 \pm 5.4 \mathrm{pmol} \mathrm{cell}^{-1}\right)$ and 'Translucid' acantharians $\left(20.9 \pm 3.6 \mathrm{pmol} \mathrm{cell}^{-1}\right)$, yet differences were only significant between $A$. elongata and Globigerinella sp. ( $p=0.03, \mathrm{~F}_{3.12}=4.1$, one-way ANOVA, Tukey's post hoc test). Analysis of DMSP concentration per cellular biovolume yielded a different picture with A. elongata $\left(17.1 \pm 6.1 \mathrm{mmol} \mathrm{L}^{-1}\right)$ having significantly higher concentrations than Foraminifera $\left(7.5 \pm 3.1 \mathrm{mmol} \mathrm{L}^{-1}\right)$, 'Star' $\left(2.4 \pm 0.7 \mathrm{mmol} \mathrm{L}^{-1}\right)$ and 'Translucid' $\left(0.3 \pm 0.1 \mathrm{mmol} \mathrm{L}^{-1}\right)$ acantharian morphotypes, while both solitary and colonial collodarian species showed significantly lower concentrations $\left(p<0.001, \mathrm{~F}_{6,16}=14.8\right)$ (Table 1).

Cellular DMSPt content in cultures of free-living algae was markedly lower (range $\left.=0.01-1.24 \mathrm{pmol} \mathrm{cell}^{-1}\right)$ according to their smaller size compared to their hosts (Table 1). Highest mean values were measured in $P$. beii $\left(0.9 \pm 0.2\right.$ pmol cell $\left.^{-1}\right)$; these were 3 -4-fold higher than in B. nutricula $\left(0.2 \pm 0.1 \mathrm{pmol} \mathrm{cell}^{-1}\right)$ while $G$. radiolariae exhibited intermediate average cell DMSPt content $\left(0.1 \pm 0.1 \mathrm{pmol} \mathrm{cell}^{-1}\right)$. DMSPt concentration calculated from microscope-based estimates of cellular biovolume in free-living algae was one-to-three orders of magnitude higher than concentration in the radiolarian and foraminiferan holobionts (Table 1). B. nutricula $\left(490 \pm 107 \mathrm{mmol} \mathrm{L}^{-1}\right)$ and G. radiolariae $(462 \pm 168 \mathrm{mmol} \mathrm{L}-1)$ showed higher values than Phaeocystis RCC1383 $\left(307 \pm 47 \mathrm{mmol} \mathrm{L}^{-1}\right)$ and P. beii $(272 \pm 49 \mathrm{mmol} \mathrm{L}$ ${ }^{1}$ ), although differences were only significant for $P$. beii $\left(\mathrm{p}=0.0001, \mathrm{~F}_{3,35}=9.1\right.$, one-way ANOVA, Tukey's post hoc test). The large error associated with the mean values reflected 
changes in the DMSPt cell content and concentration in relation to growth phase and photoperiod at the time of harvesting the culture (Supporting information).

DMSP sulfur isotopic composition $\left(\boldsymbol{\delta}^{34} \boldsymbol{S}-\mathrm{DMSP}\right)$--- The mean $\delta^{34} \mathrm{~S}-\mathrm{DMSP}$ in isolated holobiont specimens of Acantharia-Phaeocystis sp. $\left(\delta^{34} \mathrm{~S}-\mathrm{DMSP}=19.8 \pm 0.4 \%\right.$ ) and Foraminifera-P. beii $\left(\delta^{34} \mathrm{~S}-\mathrm{DMSP}=20.1 \pm 0.4 \%\right.$ ) were very similar to each other, and also to the natural microbial assemblage coexisting in the same surface water $\left(\delta^{34} \mathrm{~S}-\mathrm{DMSP}=19.7 \pm\right.$ $0.4 \%$, Fig. 3). These values were slightly lower than $\delta^{34} \mathrm{~S}$ of local seawater sulfate $\left(\delta^{34} \mathrm{~S}_{-} \mathrm{SO}_{4}{ }^{2-}\right.$ $=21.5 \pm 0.5 \%$ ). In contrast, the Collodaria-Brandtodinium holobiont showed a very distinct DMSP isotopic composition $\left(\delta^{34} \mathrm{~S}-\mathrm{DMSP}=23.5 \pm 0.8 \%\right)$, significantly enriched not only compared to other symbiotic groups (Acantharia and Foraminifera) and microbial assemblage, but also compared to $\delta^{34} \mathrm{~S}_{-} \mathrm{SO}_{4}{ }^{2-}$ in seawater $\left(p<0.0001, \mathrm{~F}_{7,26}=46.9\right.$, one-way ANOVA, Fig. $3)$.

Sulfur isotopic composition for cultured microalgae showed differences among species, with Brandtodinium nutricula $\left(18.2 \pm 0.3 \%\right.$ ) showing significantly lower $\delta^{34}$ S-DMSP values compared to Phaeocystis RCC1383 (20.2 $\pm 0.4 \%$, Tukey comparison test, $p<0.001$, Fig. 3). In the case of $B$. nutricula the $\delta^{34}$ S-DMSP values were significantly depleted relative to the Collodaria- $B$. nutricula holobiont (Tukey comparison test, $p<0.0001$ ), whereas the $\delta^{34} \mathrm{~S}$ DMSP values of free-living Phaeocystis RCC1383 was not significantly different from that measured in the Acantharia-Phaeocystis holobionts (Fig. 3).

Sulfate assimilation into DMSP and $\delta^{34}$ S fractionation --- Free-living microalgae growing in the 'Light' medium showed a progressive ${ }^{34} \mathrm{~S}$ depletion of DMSP both with time and relative to microalgae growing in the 'Heavy' medium, indicating active sulfate assimilation from seawater for DMSP biosynthesis (Fig. 4a, b). Although relatively constant during the 3-day incubation, the $\delta^{34} \mathrm{~S}$-DMSP of the microalgae growing in the 'Heavy' media 15 
was depleted relative to the seawater sulfate. The depletion was more pronounced for $B$. nutricula (-3\%) than for Phaeocystis RCC1383 (-1\%o) (Fig. 4a, b). Contrary to free-living microalgae, $\delta^{34}$ S-DMSP in symbiotic Radiolaria incubated in 'Light' and 'Heavy' media remained similar and substantially ${ }^{34} \mathrm{~S}$-enriched relative to available sulfate sources during the incubation (Fig. 4c).

DMSP to DMS conversion and sulfur isotope fractionation --- $\delta^{34} \mathrm{~S}$ of DMSP and derived DMS measured after daylight incubations showed differences between freshlycollected microbial assemblages and photosymbiotic radiolarians (Fig. 5). Sulfur isotopic composition of DMS measured from wsw, which contained the bulk microbial assemblage $(19.7 \pm 0.3 \%$ ) , was not significantly different from that measured in DMSP $(19.4 \pm 0.1 \%$,

Fig. 5). Conversely, $\delta^{34}$ S-DMS measured from incubations containing photosymbiotic Radiolaria (Acantharia-Phaeocystis holobiont, $f s w+r a d s)$ was significantly lower $(18.4 \pm 0.4$ $\% ; p<0.0001, \mathrm{~F}_{5,14}=12$, one-way ANOVA). Specifically, DMS- $\delta^{34} \mathrm{~S}$ values measured in the incubations with Radiolaria were significantly depleted relative to $\delta^{34}$ S-DMSPt values in both A. elongata (1.2\%o mean difference) and 'Star' radiolarian morphotypes (1.5 \%o mean difference). Similarly, $\delta^{34} \mathrm{~S}-\mathrm{DMS}$ in $f s w$-only treatment incubated in parallel $(18.0 \pm 0.5 \%$ o $)$ was depleted relative to $\delta^{34} \mathrm{~S}-\mathrm{DMSP}$ in microbial assemblage and Radiolaria holobionts (Fig. $5)$.

\section{DISCUSSION}

DMSP cellular content in photosymbiotic plankton and partition among partners ---

The role of DMSP in coral symbiosis has received considerable attention in recent years revealing high cell concentration and content of DMSP in the holobiont and different Symbiodinium sp. strains (Broadbent et al. 2002; Steinke et al. 2011; Deschaseaux et al. 2014) and DMS production associated to coral reefs (Broadbent and Jones 2004; Raina et al. 2010; 16 
Exton et al. 2015; Frade et al. 2016). One of the objectives of this study was to determine whether photosymbiosis in planktonic organisms is systematically associated with high concentrations of cellular DMSP. The high concentration and cellular content of DMSP measured in symbiotic microalgal species cultured in their free-living stage but originally isolated from Radiolaria and Foraminifera hosts (Table 1) is consistent with this hypothesis. Highest DMSPt concentrations were observed among dinoflagellate strains (Table 1), which are within the upper range of previously reported values for this phytoplankton class (Caruana and Malin 2014). Although elevated DMSP concentrations are characteristic of Dinophyceae and Prymnesiophyceae (Keller et al. 1989), the extremely high concentrations associated with the symbiotic partners of Collodaria and planktonic Foraminifera, is suggestive of DMSP being an important attribute of the algal partner in rhizarian symbiotic associations.

The endosymbiotic nature of the Radiolarian-microalgae associations precludes direct measurements of the DMSP content in symbiotic microalgae cells within the radiolarian host (i.e. in hospite). However, the DMSP concentrations estimated for microalgae, based on the DMSP content in the holobiont and the number of microalgae cells hosted, yielded extremely high concentrations (Table 1) that matched the highest values estimated for photosymbiotic anemone and coral species (Broadbent et al. 2002; Van Alstyne et al. 2006). In the case of the colonial and solitary Radiolaria-microalgae holobiont, DMSP content per cell estimated for $B$. nutricula in hospite was 3-, 8-fold and 20-fold higher than for free-living cells, respectively. This difference was even larger for Phaeocystis sp. with 64-100-fold higher cellular content estimated for symbiotic algae in 'A. elongata' and 'Translucid' morphotypes of Acantharia, respectively, compared to the free-living algae, which would result in unrealistic $(40-60 \mathrm{mM}$ DMSP) cellular concentrations. In other words, if the 15-38 pmol DMSP cell ${ }^{-1}$ measured in the Acantharia-Phaeocystis sp. partnership (Table 1) was allocated entirely to symbiotic algae 
with similar concentrations to those measured in free-living cultures, the host should harbor 1250-3000 algal cells, which is a 100-fold more than the 10-20 cells commonly found in its cytoplasm. Acknowledging the limits of our data, these calculations suggest that DMSP could be present in the host as well. Whether the DMSP is translocated from the algae to the host (Van Alstyne et al. 2009) and/or produced by the latter (Raina et al. 2013) cannot be concluded from concentration measurements alone. Regardless of its origin, the moderate-tohigh cellular content of DMSP estimated for the host and the algae are consistent with recent observations in Radiolaria (Decelle et al. 2012) and other photosymbiotic organisms (Hill et al. 2000; Stefels 2000; Broadbent et al. 2002; Van Alstyne et al. 2006), and suggest that both partners could mutually benefit from one or more of the multiple eco-physiological roles attributed to dimethyl sulfur compounds, e.g., osmoregulation, oxidant scavenger or infochemical (Stefels 2000; Seymour et al. 2010; Raina et al. 2013).

\section{Sulfate assimilation and DMSP production in photosymbiotic associations - Highly}

enriched $\delta^{34}$ S-DMSP observed in Collodaria-Brandtodinium sp. holobiont specimens $(23.5 \pm$ $0.8 \%$; Fig. 3) was particularly unexpected. This association showed significantly enriched $\delta^{34} \mathrm{~S}-\mathrm{DMSP}$ not only relative to seawater $\mathrm{SO}_{4}{ }^{2-}$ but also compared to other symbiotic radiolarians and all measurements previously reported for both macro- and microalgae, which showed a slight ${ }^{34}$ S-depletion in DMSP compared to seawater $\mathrm{SO}_{4}{ }^{2-}$ (Oduro et al. 2012; Amrani et al. 2013; Said-Ahmad and Amrani 2013)(Fig. 3). This distinctive sulfur isotopic composition could result from differential fractionation associated with the multi-step assimilation of sulfate into methionine (intracellular precursor to DMSP) and/or may reflect differences in the DMSP biosynthetic pathway. The $1-3 \%{ }^{34} \mathrm{~S}$ depletion in DMSP relative to sulfate during assimilation of sulfate is in agreement with previous reports (e.g. Kaplan \& Rittenberg 1964). All three biosynthetic pathways for DMSP described to date for higher 
plants and algae rely on assimilatory sulfate reduction (Gage et al. 1997; Summers et al. 1998). However, our incubation experiments with isotopically distinct sulfate solutions showed that while free-living microalgae did actively take up and assimilate sulfate into DMSP in time scales relevant for phytoplankton growth (Fig. 4a, b), collodarians with elevated cellular content of DMSP showed no isotopic evidence of assimilatory sulfate reduction into DMSP (Fig. 4c). This could be due to slower growth rates of these giant protists compared to microalgae, although the high photosynthetic rates of solitary Radiolaria (Caron et al. 1995) and abundance of endosymbiotic microalgae in incubated specimens (Table 1, Fig.1) could suggest additional explanations to the lack of sulfate uptake. The holobiont may for instance rely on inorganic or reduced sulfur species (e.g. methionine, cysteine) stored by the algae for DMSP synthesis. Radiolarians are active grazers (Anderson 1978; Swanberg and Anderson 1985; Suzuki and Not 2015), and captured prey and digestion products could provide such sulfur compounds to the symbiotic microalgae, reducing its dependence on sulfate uptake. It is worth noting however, that the assimilatory sulfate reduction only represents a small proportion of the total energetic cost (NADPH and ATP molecules) associated with de novo synthesis of DMSP (Lavoie et al. 2016).

In contrast to the collodarians, the $\delta^{34} \mathrm{~S}$-DMSP measured in individual specimens of Acantharia-Phaeocystis $(19.8 \pm 0.4 \%$ ) and Globigerinella sp.-P. beii $(20.1 \pm 0.4 \%$ ), was very similar to the isotopic composition obtained from simultaneous $(19.7 \pm 0.4 \%$ ) and previously reported bulk $\delta^{34} \mathrm{~S}-\mathrm{DMSP}$ measurements of surface microbial assemblages $(19.7 \pm 0.5 \%$, Amrani et al. 2013) (Fig. 3). In this regard, the $\delta^{34}$ S-DMSP of cultured Phaeocystis RCC1383 was similar to that measured in the Acantharia-Phaeocystis sp. holobiont (Fig. 3). The reasons for the different sulfur isotopic behavior between Acantharia-Phaeocystis sp. and Collodaria-B. nutricula associations is unclear to us, but given the phylogenetically distant 
microalgal partners involved in these symbiotic association (i.e. Dinophyceae and Prymnesiophyceae), this isotopic variability could reflect differences in the metabolic capacities of the symbiotic algae and/or the holobiont. Differences in $\delta^{34}$ S-DMSP observed between B. nutricula and Phaeocystis RCC1383 (Fig. 3) were of similar magnitude to those reported between macro and microalgae species (Oduro et al. 2012). The observed differences between the two algal strains and the remarkably distinct $\delta^{34}$ S-DMSP observed in freshly collected Collodaria-B. nutricula associations (Fig. 3) contrast with the homogeneity in $\delta^{34}$ SDMSP composition observed across diverse marine microbial communities (Amrani et al. 2013) and illustrate the isotopic variability potentially hidden in natural microbial communities. Little is known about the isotopic variability associated with taxonomic and functional diversity of major DMSP producers. Nonetheless, if adequately characterized, this variability offers an opportunity not only to investigate physiological differences between species in the lab, but also to refine our current ability to track specific sources of DMSP, and derived DMS, in highly intermixed and diverse natural microbial communities (Kaye 1987;

Calhoun et al. 1991; Said-Ahmad and Amrani 2013).

Sulfur isotope fractionation associated with DMSP cleavage into DMS --- In addition to the sulfur isotopic composition of DMSP, it is important to constrain the isotopic fractionation associated with the cleavage of DMSP into DMS. The two previous studies assessing this fractionation reported contradictory patterns; Oduro et al. (2012) reported ${ }^{34} \mathrm{~S}$ depletion for the DMS produced by macroalgae, while Amrani et al. (2013) reported small to negligible ${ }^{34} \mathrm{~S}$ enrichment from parallel measurements of DMSP and DMS in situ. Our results from the experimental incubations conducted with natural microbial assemblages and symbiotic radiolarians (Fig. 5), although limited in data and scope, offer new insights that may contribute to reconcile contrasting previous observations. It is important to note that we 
477 are not calculating fractionation factors $(\alpha)$, but rather apparent fractionation $\left(\Delta^{34} S\right)$ from the

478 difference between the product and the reactant. Consistent with Amrani et al. (2013), $\delta^{34} \mathrm{~S}-$

479 DMSP and $\delta^{34}$ S-DMS values were similar in whole seawater incubated from the Red Sea,

480 suggesting negligible fractionation is associated with microbial cleavage of DMSP. However,

481 the $\delta^{34} \mathrm{~S}$ value of DMS produced by symbiotic acantharians was lower $(-1.2,-1.5 \%$ o $)$ than that

482 of DMSP (Fig. 5), resulting in a DMS fractionation similar in sign and magnitude to that

483 reported for macroalgae by Oduro et al. (2012). These differences in the DMSP to DMS

484 fractionation between the microbial assemblage, symbiotic radiolarians and macroalgae may

485 reflect their taxonomic and functional diversity. However, similar ${ }^{34}$ S depletion of DMS was

486 observed between $f s w$-only and $f s w+$ rads incubations (Fig. 5). Evidences exist that the

487 filtration process can break phytoplankton cells and enrich the filtered seawater with

488 dissolved DMSP and extracellular activity of DMSPlyase (Kiene and Slezak 2006) to the

489 point that it is common to measure substantial DMS production in fsw (Galí et al. 2011).

490 During the 4-hour experiments, DMS was produced in both $f s w$-only and $f s w+r a d s$

491 incubations, although, the latter, containing approximately 100 specimens of Acantharia (see

methods), produced larger amounts of DMS (Fig. 5). Overall, $\delta^{34}$ S values of DMS produced

493 in natural microbial communities were similar or slightly higher than $\delta^{34} \mathrm{~S}$ values of DMSP

494 (Amrani et al., 2013; this study), while cultures or incubations with isolated organisms in

495 filtered seawater produced ${ }^{34}$ S-depleted DMS (Oduro et al., 2012; this study). This may

496 reflect the interplay among DMS sources and sinks: DMSPlyase selection for DMSP with

497 lower $\delta^{34} \mathrm{~S}$ would produce ${ }^{34} \mathrm{~S}$ depleted DMS, but preference of DMS-consumption processes

498 (e.g. bacterial uptake, photochemistry, ventilation, and bacterial uptake) for ${ }^{34}$ S-depleted DMS

499 would buffer the overall result. This possibility was already discussed by Amrani et al.

500 (2013), who invoked these DMS removal processes as potential mechanisms contributing to 
're-enrich' the DMS pool. To further constrain the contribution of each physical and biological process to this putative isotopic compensatory effect, we can compare their prevalence in the different incubations and natural measurements available from this and previous studies. The effect of ventilation can be ruled out because our incubation bottles did not allow for gas-exchange; also, the fact that the fractionation buffering effect had been observed at depths were ventilation is low further underscores the minor influence of ventilation (Amrani et al. 2013). The similarity in the light conditions for the three incubation types (wsw, $f s w$-only, and $f s w+r a d s)$, seem to argue against the effect of photochemistry upon DMS fractionation as well. Finally, although not directly measured, bacterial abundance, and likely bacterial DMS consumption, should have been largely suppressed in 0.2 um-filtered seawater during the short duration (4-hours) incubations. Filtered seawater showed ${ }^{34} \mathrm{~S}$ depletion of DMS relative to DMSP (Oduro et al. 2012; $f$ sw-only incubation this study) while whole seawater, containing natural abundances of bacteria, showed similar $\delta^{34} \mathrm{~S}$ values for DMS and DMSP (Amrani et al. 2013; wsw incubation this study, Fig. 2b). These observations are not sufficient to confirm, but are consistent with, a hypothetical scenario where bacterial uptake contributes the most to the homogenization of $\delta^{34} \mathrm{~S} \mathrm{DMS}(\mathrm{P})$ in natural settings. Future experiments assessing 1) the fractionation towards ${ }^{34}$ S depleted DMS preference of DMSP lyases, and 2) the magnitude and sign of the sulfur isotopic fractionation associated with bacterial uptake are needed to test this hypothesis.

\section{Photosymbiosis contribution to the marine sulfur cycle --- Current understanding of} DMS(P) cycling in pelagic ecosystems recognizes phytoplankton, particularly the nano-size fraction $(2-20 \mu \mathrm{m})$ with abundant representatives of high DMSP producer classes such as Prymnesiophyceae and Dinophyceae, and also diatoms (Bucciarelli et al. 2013), as the primary DMSP producers (Keller et al. 1989; Stefels et al. 2007). However, the concentration 
of DMSP observed in symbiotic Radiolaria and Foraminifera, suggests that larger photosymbiotic plankton $(50-2000 \mu \mathrm{m})$ that harbor photosynthetic endosymbionts from these same phytoplankton groups (Siano et al. 2010; Decelle et al. 2012; Probert et al. 2014; Yuasa et al. 2016), can represent a significant source of marine DMS(P) particularly in (sub)tropical latitudes where high abundances have been reported (Caron et al. 1995; Dennett et al. 2002; Biard et al. 2016). To evaluate this hypothesis we calculated the Radiolaria-associated contribution to total water column DMSP in the euphotic zone of a number of stations from the (sub)tropical-oriented Tara Oceans expedition track, using the mean group-specific DMSP concentration for Radiolaria (Table 1) and in situ abundance and biovolume obtained with the Underwater Video Profiler (UVP)(Biard et al. 2016), and micro- and nanophytoplankton-associated DMSP estimated from chlorophyll-based empirical relationships (Belviso et al. 2004). The potential contribution of large symbiotic Radiolaria (UVP lower detection threshold $=600 \mu \mathrm{m})$ to water column DMSP was low on average $(1.1 \pm 2.2 \%$, mean $\pm \mathrm{SD}, \mathrm{n}=19)$ although peaks of moderate contribution (8\%) were inferred associated with Acantharia. Despite being inefficiently captured by the UVP - Acantharia are numerically dominated by $<150 \mu \mathrm{m}$ forms (Michaels 1988; Caron and Swanberg 1990) - these group of Radiolaria potentially contribute the most DMSP in virtue of their high DMSP intracellular concentration. Moreover, the Radiolaria-associated DMSPt may represent an important source of sulfur for higher trophic levels that cannot effectively prey on smaller nanophytoplankton. Considering all these caveats, this conservative approximation indicates that photosymbiotic plankton can represent a significant source of DMS(P), particularly in tropical and subtropical oceans, where the high DMSP producers that are typical of temperate and sub-polar latitudes (e.g. E. huxleyi or Phaeocystis sp.), are less abundant and Radiolaria and Foraminifera represent an important component of plankton communities (Caron et al. 
549 1995; Decelle et al. 2015; Biard et al. 2016), and can account for up to $20 \%$ of primary

550 production (Michaels 1988). In this regard, the distinct sulfur isotopic composition of DMSP

551 in Collodaria-Brandtodinium holobiont, one of the most abundant and ecologically relevant

552 group of photosymbiotic plankton (Dennett et al. 2002; de Vargas et al. 2015; Guidi et al.

553 2016), presents the possibility of assessing the contribution of photosymbiotic plankton to

554 community DMSP production in the future. Beyond biogeochemical considerations, the

555 highly ${ }^{34}$ S enriched DMSP and the lack of apparent sulfate assimilation into DMSP observed

556 in Collodaria-Brandtodinium associations suggest that DMSP biosynthetic pathways could be

557 linked to the recycling of organic sulfur between symbiotic partners. If use of organic sulfur

558 for DMSP synthesis also occurs among free-living phytoplankton, we may be able to

559 discriminate between 'new' (from sulfate) vs 'recycled' (from organic S) DMSP production

560 by their differential S-isotopic signature, in a similar way to approaches using nitrogen

561 isotopes to apportion new and recycled nitrogen sources for primary production. 


\section{References}

564

565

566

567

568

569

570

571

572

573

574

575

576

577

578

579

580

581

582

583

584

585

586

Amrani, A., W. Said-Ahmad, Y. Shaked, and R. P. Kiene. 2013. Sulfur isotope homogeneity of oceanic DMSP and DMS. Proc. Natl. Acad. Sci. U S A 110: 18413-18418.

Amrani, A., A. L. Sessions, and J. F. Adkins. 2009. Compound-specific delta s-34 analysis of volatile organics by coupled GC/multicollector-ICPMS. Anal. Chem. 81: 9027-9034.

Anderson, O. R. 1978. Light and electron-microscopic observations of feeding-behavior, nutrition, and reproduction in laboratory cultures of thalassicolla-nucleata. Tissue \& Cell 10: 401-412.

---. 1983. Radiolaria. Springer.

Andreae, M. O. 1997. Atmospheric aerosols: Biogeochemical sources and role in atmospheric chemistry. Science 276: 1052-1058.

Bates, T. S., B. K. Lamb, A. Guenther, J. Dignon, and R. E. Stoiber. 1992. Sulfur emissions to the atmosphere from natural sources. J. Atmos. Chem. 14: 315-337.

Belviso, S., C. Moulin, L. Bopp, and J. Stefels. 2004. Assessment of a global climatology of oceanic dimethylsulfide (DMS) concentrations based on seawifs imagery (1998-2001). Can. J. Fish. Aquat. Sci. 61: 804-816.

Berges, J. A., D. J. Franklin, and P. J. Harrison. 2001. Evolution of an artificial seawater medium: Improvements in enriched seawater, artificial water over the last two decades. J. Phycol. 37: 1138-1145.

Biard, T., and others. Global in situ imaging observations reveal the biomass of rhizaria in the oceans. DOI 10.1038/nature17652

Blunden, G., B. E. Smith, M. W. Irons, M. H. Yang, O. G. Roch, and A. V. Patel. 1992. Betaines and tertiary sulfonium compounds from 62 species of marine-algae. Biochem. Syst. Ecol. 20: 373-388. 
Broadbent, A. D., and G. B. Jones. 2004. DMS and DMSP in mucus ropes, coral mucus, surface films and sediment pore waters from coral reefs in the great barrier reef. Mar. Freshwater Res. 55: 849-855.

Broadbent, A. D., G. B. Jones, and R. J. Jones. 2002. DMSP in corals and benthic algae from the great barrier reef. Estuar. Coast. Shelf Sci. 55: 547-555.

Bucciarelli, E., C. Ridame, W. G. Sunda, C. Dimier-Hugueney, M. Cheize, and S. Belviso. 2013. Increased intracellular concentrations of DMSP and DMSO in iron-limited oceanic phytoplankton thalassiosira oceanica and trichodesmium erythraeum. Limnol. Oceanogr. 58: 1667-1679.

Calhoun, J. A., T. S. Bates, and R. J. Charlson. 1991. Sulfur isotope measurements of submicrometer sulfate aerosol-particles over the pacific-ocean. Geophys. Res. Lett. 18: $1877-1880$.

Caron, D. A., P. D. Countway, A. C. Jones, D. Y. Kim, and A. Schnetzer. 2012. Marine protistan diversity, p. 467-493. In C. A. Carlson and S. J. Giovannoni [eds.], Annual review of marine science, vol 4. Ann. Rev. Mar. Sci.

Caron, D. A., A. F. Michaels, N. R. Swanberg, and F. A. Howse. 1995. Primary productivity by symbiont-bearing planktonic sarcodines (acantharia, radiolaria, foraminifera) in surface waters near bermuda. J. Plankton Res. 17: 103-129.

Caron, D. A., and N. R. Swanberg. 1990. The ecology of planktonic sarcodines. Rev. Aquat. Sci. 3: $147-180$.

Caruana, A. M. N., and G. Malin. 2014. The variability in DMSP content and DMSP lyase activity in marine dinoflagellates. Prog. Oceanogr. 120: 410-424.

Charlson, R. J., J. E. Lovelock, M. O. Andreae, and S. G. Warren. 1987. Oceanic phytoplankton, atmospheric sulfur, cloud albedo and climate. Nature 326: 655-661. 
de Vargas, C., and others 2015. Eukaryotic plankton diversity in the sunlit ocean. Science 348.

Decelle, J., S. Colin, and R. A. Foster. 2015. Photosymbiosis in marine planktonic protists. In S. Ohtsuka and T. Suzaki, Horiguchi, T., Suzuki, N., Not, F. [eds.], Marine protists diversity and dynamics. Springer.

Decelle, J., and others 2012. An original mode of symbiosis in open ocean plankton. Proc. Natl. Acad. Sci. U S A 109: 18000-18005.

Dennett, M. R., D. A. Caron, A. F. Michaels, S. M. Gallager, and C. S. Davis. 2002. Video plankton recorder reveals high abundances of colonial radiolaria in surface waters of the central north pacific. J. Plankton Res. 24: 797-805.

Deschaseaux, E. S. M., and others 2014. Effects of environmental factors on dimethylated sulfur compounds and their potential role in the antioxidant system of the coral holobiont. Limnol. Oceanogr. 59: 758-768.

Exton, D. A., T. J. McGenity, M. Steinke, D. J. Smith, and D. J. Suggett. 2015. Uncovering the volatile nature of tropical coastal marine ecosystems in a changing world. Glob. Chang. Biol. 21: 1383-1394.

Frade, P., V. Schwaninger, B. Glasl, R. W. Hill, R. Simó, and G. J. Herndl.2016. Dimethylsulfoniopropionate in corals and its interrelations with bacterial assemblages in coral surface mucus. Environ. Chem. 13: 252-265.

Gage, D. A., D. Rhodes, K. D. Nolte, W. A. Hicks, T. Leustek, A. J. L. Cooper, and A. D. Hanson. 1997. A new route for synthesis of dimethylsulphoniopropionate in marine algae. Nature 387: 891-894.

Gali, M., V. Salo, R. Almeda, A. Calbet, and R. Simó. 2011. Stimulation of gross dimethylsulfide (DMS) production by solar radiation. Geophys. Res. Lett. 38. 
Garces, E., E. Alacid, A. Rene, K. Petrou, and R. Simó. 2013. Host-released dimethylsulphide activates the dinoflagellate parasitoid parvilucifera sinerae. ISME J. 7: 1065-1068.

Giesemann, A., H. J. Jager, A. L. Norman, H. P. Krouse, and W. A. Brand. 1994. Online sulfur-isotope determination using an elemental analyzer coupled to a massspectrometer. Anal. Chem. 66: 2816-2819.

Guidi, L., S. Chaffron, L. Bittner and others. 2016. Plankton networks driving carbon export in the oligotrophic ocean. Doi:10.108/nature16942

Hill, R. W., J. W. H. Dacey, and A. Edward. 2000. Dimethylsulfoniopropionate in giant clams (tridacnidae). Biol. Bull. 199: 108-115.

Kaplan, I. R., and S. C. Rittenberg. 1964. Microbiological fractionation of sulphur isotopes. J. Gen. Microbiol. 34: 195-212.

Karsten, U., S. Koch, J. A. West, and G. O. Kirst. 1996. Physiological responses of the eulittoral macroalga stictosiphonia hookeri (rhodomelaceae, rhodophyta) from argentina and chile: Salinity, light and temperature acclimation. Eur. J. Phycol. 31: 361-368.

Kaye, J. A. 1987. Mechanisms and observations for isotope fractionation of molecular-species in planetary-atmospheres. Rev Geophys 25: 1609-1658.

Keller, M. D., Selvin, R. C., Claus, W. \& Guillard, R. R. L. 1987. Media for the culture of oceanic ultraphytoplankton. J. Phycol. 23:633-8.

Keller, M. D., W. K. Bellows, and R. R. L. Guillard. 1989. Dimethyl sulfide production in marine phytoplankton Acs Symposium Series 393: 167-182.

Kiene, R., and D. Slezak. 2006. Low dissolved DMSP concentrations in seawater revealed by small-volume gravity filtration and dialysis sampling. Limnol. Oceanogr. Methods 4: 80-95. 
Kirst, G. O. 1990. Salinity tolerance of eukaryotic marine-algae. Annu. Rev. Plant. Biol. 41: 21-53.

Kirst, G. O., C. Thiel, H. Wolff, J. Nothnagel, M. Wanzek, and R. Ulmke. 1991. Dimethylsulfoniopropionate (DMSP) in ice-algae and its possible biological role. Mar. Chem. 35: 381-388.

Lana, A., R. Simó, S. M. Vallina, and J. Dachs. 2012. Re-examination of global emerging patterns of ocean DMS concentration. Biogeochemistry 110: 173-182.

Lavoie, M., Levasseur, M., and M. Babin. 2015. Testing the potential ballast role for dimethylsulfoniopropionate in marine phytoplankton: A modeling study. J Plankton Res. 0:1-13.

Lavoie, M., Raven, J. A., and M. Levasseur. 2016. Energy cost and putative benefits of cellular mechanisms modulating buoyancy in a flagellate marine phytoplankton. J. Phycol. 52:239-51.

Lyon, B. R., J. M. Bennett, P. A. Lee, M. G. Janech, and G. R. DiTullio. 2016 Role of dimethylsulfoniopropionate as an osmoprotectant following gradual salinity shifts in the sea-ice diatom fragilariopsis cylindrus. Environ. Chem. 13: 181-194.

Malin, G., and M. Steinke. 2004. Dimethyl sulfide production: What is the contribution of the coccolithophores? In: Thierstein HR, Young JR (eds) Coccolithophores: from molecular processes to global impact. Springer, Berlin, p 127-164

Marie, D., F. Partensky, S. Jacquet, and D. Vaulot. 1997. Enumeration and cell cycle analysis of natural populations of marine picoplankton by flow cytometry using the nucleic acid stain SYBR green I. Applied and environmental microbiology 63: 186-193.

Michaels, A. F. 1988. Vertical-distribution and abundance of acantharia and their symbionts. Mar. Biol. 97: 559-569. 
Norman, A. L., L. A. Barrie, D. Toom-Sauntry, A. Sirois, H. R. Krouse, S. M. Li, and S. Sharma. 1999. Sources of aerosol sulphate at alert: Apportionment using stable isotopes. J. Geophys. Res.: Atmospheres 104: 11619-11631.

Not, F., J. del Campo, V. Balague, C. de Vargas, and R. Massana. 2009. New insights into the diversity of marine picoeukaryotes. Plos One 4: e7143

Nowack, E. C., and M. Melkonian. 2010. Endosymbiotic associations within protists. Phil. Trans. R. Soc. B, Biol. Sci. 365: 699-712.

Oduro, H., K. L. Van Alstyne, and J. Farquhar. 2012. Sulfur isotope variability of oceanic DMSP generation and its contributions to marine biogenic sulfur emissions. Proc. Natl. Acad. Sci. U S A 109: 9012-9016.

Patris, N., R. Delmas, M. Legrand, M. De Angelis, F. A. Ferron, M. Stiévenard, and J. Jouzel. 2002. First sulfur isotope measurements in central greenland ice cores along the preindustrial and industrial periods. J. Geophys. Res: Atmos 107: ACH 6-1-ACH 611.

Probert, I., R. Siano, C. Poirier and others 2014. Brandtodinium gen. Nov. And b. Nutricula comb. Nov. (dinophyceae), a dinoflagellate commonly found in symbiosis with polycystine radiolarians. J. Phycol. 50: 388-399.

Quinn, P. K., and T. S. Bates. 2011. The case against climate regulation via oceanic phytoplankton sulphur emissions. Nature 480: 51-56.

Raina, J. B., E. A. Dinsdale, B. L. Willis, and D. G. Bourne. 2010. Do the organic sulfur compounds DMSP and DMS drive coral microbial associations? Trends Microbiol. 18: $101-108$.

Raina, J. B., D. M. Tapiolas, S. Foret and others 2013. DMSP biosynthesis by an animal and its role in coral thermal stress response. Nature 502: 677-680. 
Said-Ahmad, W., and A. Amrani. 2013. A sensitive method for the sulfur isotope analysis of dimethyl sulfide and dimethylsulfoniopropionate in seawater. Rapid Commun. Mass Sp.: RCM 27: 2789-2796.

Savoca, M. S., and G. A. Nevitt. 2014. Evidence that dimethyl sulfide facilitates a tritrophic mutualism between marine primary producers and top predators. Proc. Natl. Acad. Sci. U S A 111: 4157-4161.

Schoemann, V., S. Becquevort, J. Stefels, V. Rousseau, and C. Lancelot. 2005. Phaeocystis blooms in the global ocean and their controlling mechanisms: A review. J. Sea. Res. 53: 43-66.

Seymour, J. R., R. Simó, T. Ahmed, and R. Stocker. 2010. Chemoattraction to dimethylsulfoniopropionate throughout the marine microbial food web. Science 329: $342-345$.

Siano, R., M. Montresor, I. Probert, F. Not, and C. de Vargas. 2010. Pelagodinium gen. Nov. And p. Beii comb. Nov., a dinoflagellate symbiont of planktonic foraminifera. Protist 161: 385-399.

Simó, R. 2001. Production of atmospheric sulfur by oceanic plankton: Biogeochemical, ecological and evolutionary links. Trends Ecol. Evol. 16: 287-294.

Stefels, J. 2000. Physiological aspects of the production and conversion of DMSP in marine algae and higher plants. J. Sea. Res. 43: 183-197.

Stefels, J., M. Steinke, S. Turner, G. Malin, and S. Belviso. 2007. Environmental constraints on the production and removal of the climatically active gas dimethylsulphide (DMS) and implications for ecosystem modelling. Biogeochemistry 83: 245-275. 
Steinke, M., P. Brading, P. Kerrison, M. E. Warner, and D. J. Suggett. 2011. Concentrations of dimethylsulfoniopropionate and dimethyl sulfide are strain-specific in symbiotic dinoflagellates (symbiodinium sp., dinophyceae). J. Phycol. 47: 775-783.

Stemmann, L., M. Youngbluth, K. Robert and others 2008. Global zoogeography of fragile macrozooplankton in the upper 100-1000 $\mathrm{m}$ inferred from the underwater video profiler. ICES J. Mar. Sci. 65: 433-442.

Stoecker, D. K., M. D. Johnson, C. deVargas, and F. Not. 2009. Acquired phototrophy in aquatic protists. Aquat. Microb. Ecol. 57: 279-310.

Summers, P., K. Nolte, A. Cooper, T. Leustek, D. Rhodes, and A. Hanson. 1998. Identification and stereospecificity of the first three enzymes of 3dimethylsulfoniopropionate biosynthesis in a chlorophyte alga. Plant. Physiol. 116: 369-378.

Sunda, W., D. J. Kieber, R. P. Kiene, and S. Huntsman. 2002. An antioxidant function for DMSP and DMS in marine algae. Nature 418: 317-320.

Suzuki, N., and F. Not. 2015. Biology and ecology of radiolaria. 179-222.

Swanberg, N. R., and O. R. Anderson. 1985. The nutrition of radiolarians: Trophic activity of some solitary spurnellaria. Limnol. Oceanogr. 30: 646-652.

Vairavamurthy, A., M. O. Andreae, and R. L. Iverson. 1985. Biosynthesis of dimethylsulfide and dimethylpropiothetin by hymenomonas-carterae in relation to sulfur source and salinity variations. Limnol. Oceanogr. 30: 59-70.

Van Alstyne, K. L., V. J. Dominique, III, and G. Muller-Parker. 2009. Is dimethylsulfoniopropionate (DMSP) produced by the symbionts or the host in an anemone-zooxanthella symbiosis? Coral Reefs 28: 167-176. 
752

753

754

755

756

757

Van Alstyne, K. L., P. Schupp, and M. Slattery. 2006. The distribution of dimethylsulfoniopropionate in tropical pacific coral reef invertebrates. Coral Reefs 25: 321-327.

Yuasa, T., T. Horiguchi, S. Mayama, and O. Takahashi. 2016. Gymnoxanthella radiolariae gen. Et sp. Nov. (dinophyceae), a dinoflagellate symbiont from solitary polycystine radiolarians. J. Phycol. 52: 89-104. 
759

760

We thank the ASSEMBLE (Association of European Marine biological Laboratories)

European program for supporting the field campaigns conducted from the Interuniversity Institute for Marine Science (IUI, Israel) and the Observatory Oceanologique de Villefranche sur Mer (obs-vlfr, France). Particularly to Simon Berkowicz, Keren Zandbak and Yeala Shaked for organizing our visit and help with the sampling and experimental logistics at the IUI; John Dolan for sharing his laboratory facilities in obs-vlfr, Fabien Lombard and Sophie Marro for their time and assistance with the sampling and logistic support. Many thanks to Ian Probert and Estelle Bigeard for their invaluable contribution during the sampling and experiments set up. We are in debt with Eva Bucciarelli for generously sharing her time and analytical facilities at LEMAR (Brest, France) for DMSP analysis. We thank Cliff Law for his comments and help copy editing the document. A.G.R. was supported by a Region Bretagne postdoctoral fellowship SYMBIOX and by the National Institution for Water and Atmospheric research (NIWA, New Zealand). T.B. was supported by the UMPC Emergence program and L.P. by the SNF Seastar project. LP was supported by the Swiss National Science Foundation postdoctoral grant P2GEP3_148800. A.A. thanks the Binational Science Foundation Grant 2010407 for partial funding of this work. R.S. acknowledges support from the Spanish Ministry of Science and Innovation through the SUMMER project (CTM200803309). 


\section{Figure Captions}

779

780

781

782

783

784

785

786

787

788

789

790

791

792

793

794

795

796

797

798

799

800

801

802

803

804

805

806

807

808

809

Figure 1. Symbiotic Radiolaria and Foraminifera specimens isolated from the NW Mediterranean and Red sea surface waters imaged under the binocular (a, b, d, e, f, g) and light microscopy (c, h, i). Single-celled acantharians Amphilonche elongata (a), 'Star' (b), 'Translucid' (c) morphotypes with Phaeocystis sp. endosymbiotic algae. Single-celled Foraminifera Globigerinella sp. with Pelagodinium beii endosymbionts (d), Solitary Thalassicolla sp. (e), and colonial Sphaerozoum sp. (f, h) and Collozoum sp. (g, i) collodarian specimens with Brandtodininium nutricula endosymbionts.

Figure 2. Schematic representation of the experimental design and sequence of operations followed for (a) the sulfate assimilation and (b) the DMS production experiments described in the methods.

Figure 3. Sulfur isotopic composition of intracellular DMSP $\left(\delta^{34} \mathrm{~S}-\mathrm{DMSP}\right)$ of freshly-collected symbiotic Radiolaria (Acantharia, solid-brown; Collodaria, green stars) and Foraminifera (red square), of cultured free-living symbionts isolated from the same radiolarian groups $B$. nutricula (green triangles) and Phaeocystis (empty-brown), and of natural microbial assemblages collected from surface waters. Seawater sulfate isotopic composition $\left(\delta^{34} \mathrm{~S}-\right.$ $\mathrm{SO}_{4}{ }^{2-}$ ) (grey diamond). The range of $\delta^{34} \mathrm{~S}$-DMSP from previous measurements in a bloom of Prorocentrum minimum and isolated macroalgae (Oduro et al. 2012) and surface seawater (Amrani et al. 2013, area between dash lines) are shown as reference.

Figure 4. Sulfur isotopic composition of sulfate $\left(\delta^{34} \mathrm{~S}_{-} \mathrm{SO}_{4}{ }^{2-}\right)$ and intracellular DMSP $\left(\delta^{34} \mathrm{~S}-\mathrm{DMSP}\right)$ in cultured free-living Phaeocystis RCC1383 (A), Brandtodinium nutricula (B), and freshlycollected Collodaria-Brandtodinium holobiont (C) incubated for 3-day in two different culture media containing sulfate with standard ('Standard') and light ('Light') $\delta^{34} \mathrm{~S}_{-} \mathrm{SO}_{4}{ }^{2-}$, respectively. Cell abundance for free-living cultured microalgae incubations is shown.

Figure 5. Sulfur isotopic composition of particulate DMSP ( $\delta^{34}$ S-DMSP, black bars $)$ and dissolved DMS ( $\delta^{34}$ S-DMS, white bars) in freshly-collected symbiotic Radiolaria (AcanthariaPhaeocystis) and microbial assemblage sampled from the same waters in the Red Sea where the Radiolaria were collected, measured after 4 hours of incubation under natural sunlight conditions in surface waters. Squares with the error bars represent the concentration of dissolved DMSP (black) and DMS (white) at the end of the incubation. Error bars represent the standard error of the mean. Microbial assemblage (wsw), Radiolaria assemblage $(f s w+r a d s)$, Filtered seawater (fsw-only). 
TABLE 1. Cell and colony size, DMSPt cell content, and intracellular concentration in uncultured

811 symbiotic Radiolaria and Foraminifera (host + microalgae), and cultured free-living symbiotic

812 microalgae isolated from the same species of Radiolaria and Foraminifera. The abundance of

813 radiolarian cells per colony and the abundance of symbiont cells per holobiont were assessed from

814 image analysis of freshly-collected organisms. DMSPt cellular content per symbiont in hospite

815 estimated assuming all DMSPt measured in the holobiont is allocated in the symbiotic microalgae. Cc

816 refers to central capsule, $n / a$ and $n / d$ refer to not applicable and not determined, respectively. The

817 number of measurements are shown in brackets. The errors refer to the standard deviation of the mean.

\begin{tabular}{|c|c|c|c|c|c|c|c|}
\hline \multicolumn{3}{|c|}{ TABLE 1 (All growth phases) } & $\begin{array}{l}\text { Size (um) } \\
\text { Major } \\
\text { axis } \\
(\mu \mathrm{m})\end{array}$ & $\begin{array}{l}\text { Size (um) } \\
\text { Minor } \\
\text { axis } \\
(\mu \mathrm{m})\end{array}$ & $\begin{array}{l}\text { DMSPt } \\
\text { Content } \\
\text { pmol } \\
\text { cell }^{-1}\end{array}$ & $\begin{array}{l}\text { DMSPt } \\
\text { Concentration } \\
\mathrm{mmol} \mathrm{L}^{-1}\end{array}$ & $\begin{array}{l}\text { Number } \\
\text { central } \\
\text { capsules } \\
\text { colony }^{-1}\end{array}$ \\
\hline \multicolumn{8}{|c|}{$\begin{array}{l}\text { Collodaria-Brandtodinium sp. } \\
\text { (Radiolaria) }\end{array}$} \\
\hline Collozoum sp. & Colonial & Symbiotic & $\begin{array}{c}7267 \\
\pm 1793(3)\end{array}$ & $\begin{array}{c}3754 \\
\pm 243(3)\end{array}$ & $\begin{array}{c}3652 \\
\pm 2008(3)\end{array}$ & $\begin{array}{c}0.1 \\
\pm 0.1(3)\end{array}$ & $\begin{array}{c}509 \\
\pm 72(3)\end{array}$ \\
\hline Sphaerozoum sp. & Colonial & Symbiotic & $\begin{array}{c}8242 \\
\pm 2041(4)\end{array}$ & $\begin{array}{c}3463 \\
\pm 1327(4)\end{array}$ & $\begin{aligned} & 3135 \\
\pm & 236(3)\end{aligned}$ & $\begin{array}{c}0.1 \\
\pm 0.01(3)\end{array}$ & $\begin{array}{c}166 \\
\pm 65(17)\end{array}$ \\
\hline Thalassicolla sp. & Solitary & Symbiotic & $\begin{array}{c}3972 \\
\pm 1148(5)\end{array}$ & $\begin{array}{c}3517 \\
\pm 939(5)\end{array}$ & $\begin{aligned} & 2757 \\
\pm & 750(5)\end{aligned}$ & $\begin{array}{c}0.2 \\
\pm 0.1(5)\end{array}$ & $n / a$ \\
\hline \multicolumn{8}{|c|}{$\begin{array}{l}\text { Acantharia-Phaeocystis sp. } \\
\text { (Radiolaria) }\end{array}$} \\
\hline $\begin{array}{l}\text { Amphilonche } \\
\text { elongata }\end{array}$ & $\begin{array}{l}\text { Single- } \\
\text { celled }\end{array}$ & Symbiotic & $\begin{array}{c}391 \\
\pm 117(31)\end{array}$ & $\begin{array}{c}64 \\
\pm 30(31)\end{array}$ & $\begin{array}{c}15.2 \\
\pm 5.4(4)\end{array}$ & $\begin{array}{c}17.1 \\
\pm 6.1(4)\end{array}$ & $n / a$ \\
\hline $\begin{array}{l}\text { Translucid' } \\
\text { morphotype }\end{array}$ & $\begin{array}{l}\text { Single- } \\
\text { celled }\end{array}$ & Symbiotic & $\begin{array}{c}483 \\
\pm 188(12)\end{array}$ & $\begin{array}{c}437 \\
\pm 182(12)\end{array}$ & $\begin{array}{c}20.9 \\
\pm 3.6(3)\end{array}$ & $\begin{array}{c}0.3 \\
\pm 0.1(3)\end{array}$ & $n / a$ \\
\hline $\begin{array}{l}\text { Star shape' } \\
\text { morphotype }\end{array}$ & $\begin{array}{l}\text { Single- } \\
\text { celled }\end{array}$ & Symbiotic & $\begin{array}{c}307 \\
\pm 114(42)\end{array}$ & $\begin{array}{c}242 \\
\pm 119(42)\end{array}$ & $\begin{array}{c}36.4 \\
\pm 10.4(5)\end{array}$ & $\begin{array}{c}2.4 \\
\pm 0.7(5)\end{array}$ & $n / a$ \\
\hline \multicolumn{8}{|l|}{ Foraminifera-P. beii } \\
\hline $\begin{array}{l}\text { Globigerinella sp. } \\
\text { (Planktonic) }\end{array}$ & $\begin{array}{l}\text { Single- } \\
\text { celled }\end{array}$ & Symbiotic & $\begin{array}{l}235 \\
\pm 87(31)\end{array}$ & $\begin{array}{l}209 \\
\pm 58(31)\end{array}$ & $\begin{array}{c}37.8 \\
\pm 15.5(5) \\
\end{array}$ & $\begin{array}{l}7.5 \\
\pm 3.1(5)\end{array}$ & $n / a$ \\
\hline \multicolumn{8}{|l|}{ Free-living symbiotic } \\
\hline $\begin{array}{l}\text { Brandtodinium } \\
\text { nutricula }(\mathrm{RCC} 3468) \\
\text { (Dinophyceae) }\end{array}$ & $\begin{array}{l}\text { Single- } \\
\text { celled }\end{array}$ & Symbiotic & $\begin{array}{l}12 \\
\pm 0.9(15)\end{array}$ & $\begin{array}{l}8.6 \\
\pm 0.7(15)\end{array}$ & $\begin{array}{c}0.2 \\
\pm 0.1(12)\end{array}$ & $\begin{array}{l}490 \\
\pm 107(12)\end{array}$ & $n / a$ \\
\hline $\begin{array}{l}\text { Pelagodinium beii } \\
\text { (RCC1491) } \\
\text { (Dinophyceae) }\end{array}$ & $\begin{array}{l}\text { Single- } \\
\text { celled }\end{array}$ & Symbiotic & $\begin{array}{l}20.5 \\
\pm 1.8(18)\end{array}$ & $\begin{array}{l}17.7 \\
\pm 2.3(18)\end{array}$ & $\begin{array}{c}0.9 \\
\pm 0.2(12)\end{array}$ & $\begin{array}{l}272 \\
\pm 49(12)\end{array}$ & $n / a$ \\
\hline Gymnoxanthella & Single- & Symbiotic & 9.1 & 7.9 & 0.1 & 462 & $n / a$ \\
\hline
\end{tabular}




\begin{tabular}{|c|c|c|c|c|c|c|}
\hline $\begin{array}{l}\text { radiolariae } \\
\text { (RCC3507) } \\
\text { (Dinophyceae) }\end{array}$ & celled & & $\pm 1.0(15)$ & $\pm 0.6(15)$ & $\pm 0.1(12)$ & $\pm 168(12)$ \\
\hline $\begin{array}{l}\text { Phaeocystis } \\
\text { (RCC1383) } \\
\text { (Prymnesiophyceae) }\end{array}$ & $\begin{array}{l}\text { Single- } \\
\text { celled }\end{array}$ & Symbiotic & $\begin{array}{l}4.0 \\
\text { nominal }\end{array}$ & $\begin{array}{l}4.0 \\
\text { nominal }\end{array}$ & $\begin{array}{c}0.01 \\
\pm 0.001(3)\end{array}$ & $\begin{array}{l}307 \\
\pm 47(3)\end{array}$ \\
\hline
\end{tabular}

818

819

820 


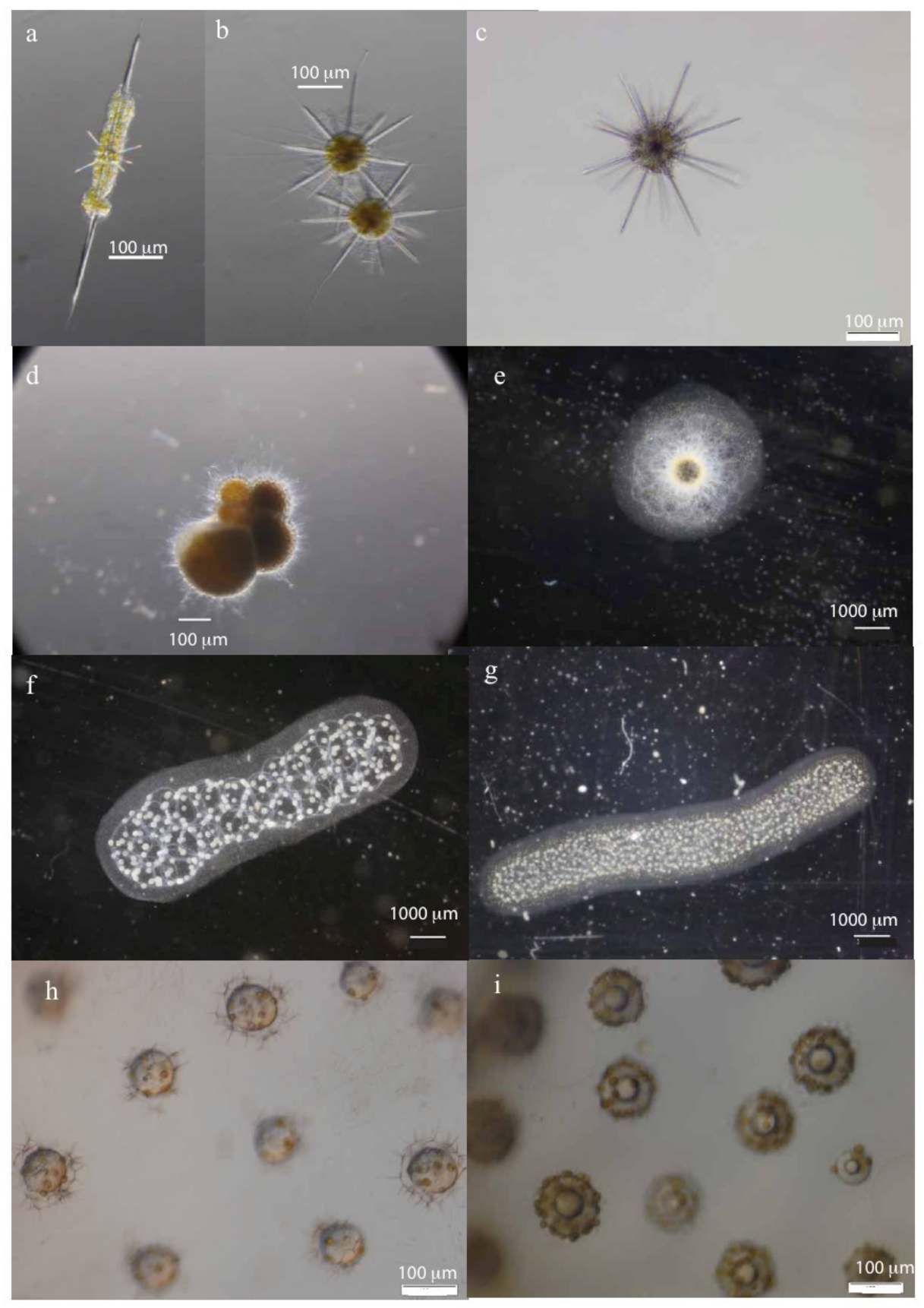


826 Figure 2

827

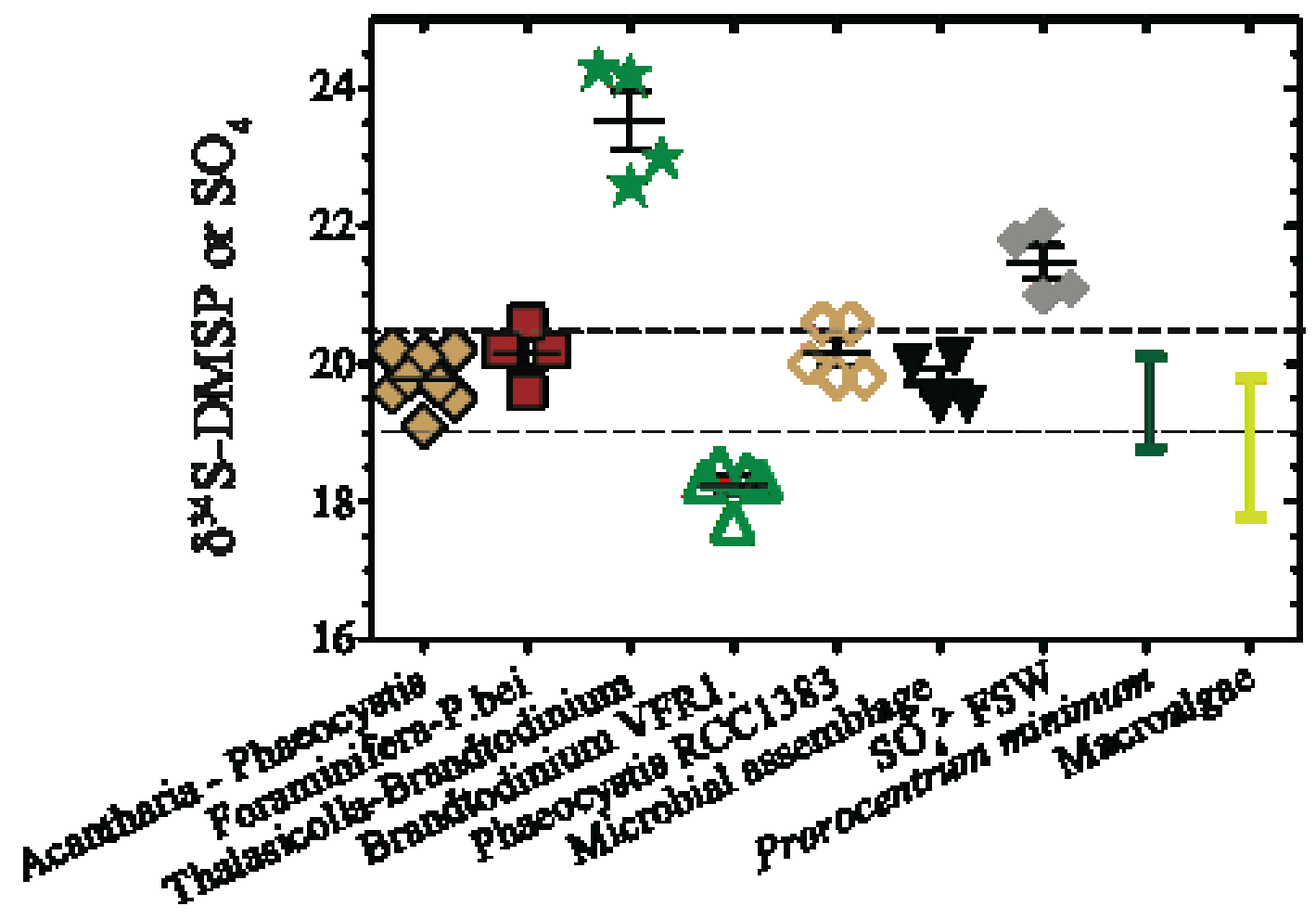

828

829

830

831

832

833

834

835 
a - Sufate assimlation exparimant
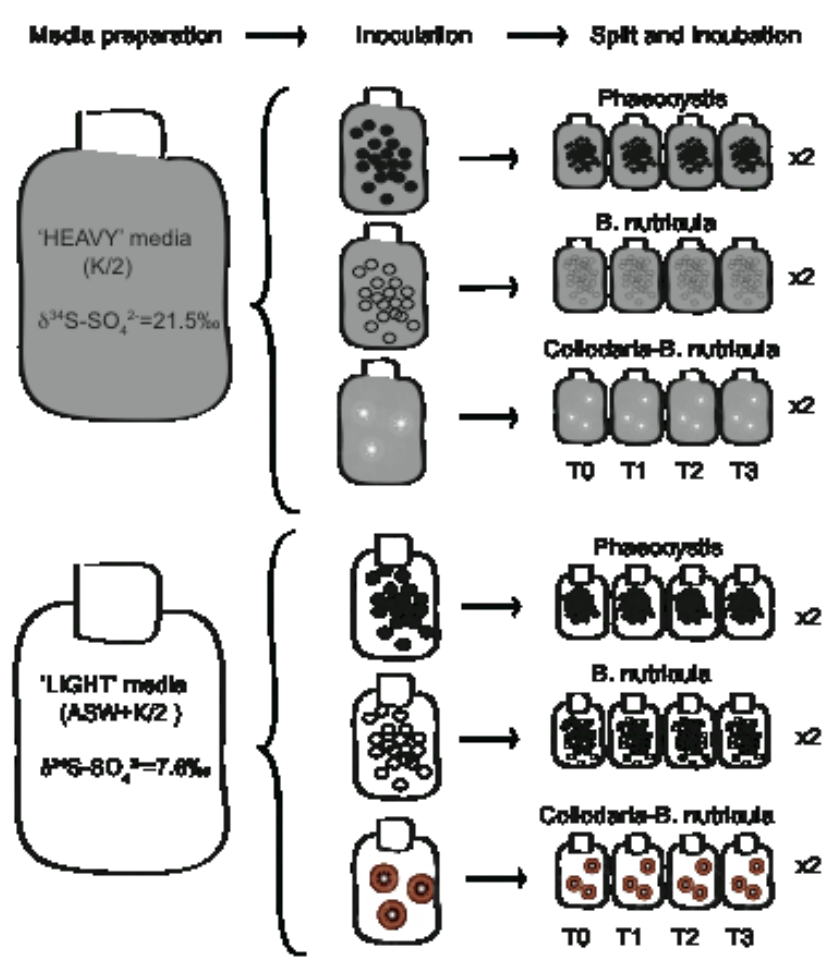

b- DMS pnoduction experimant

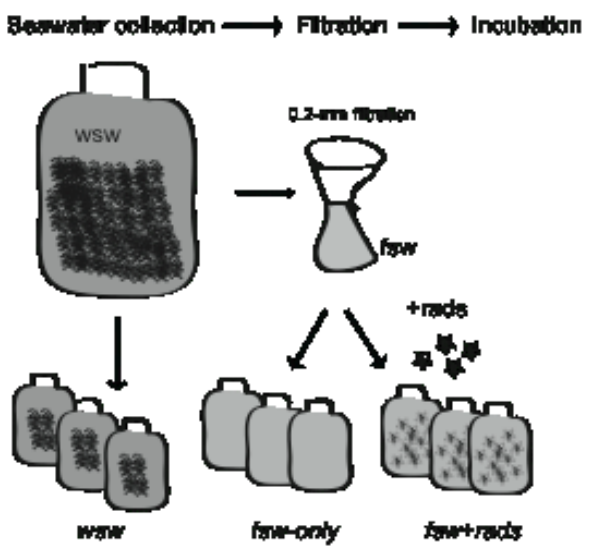



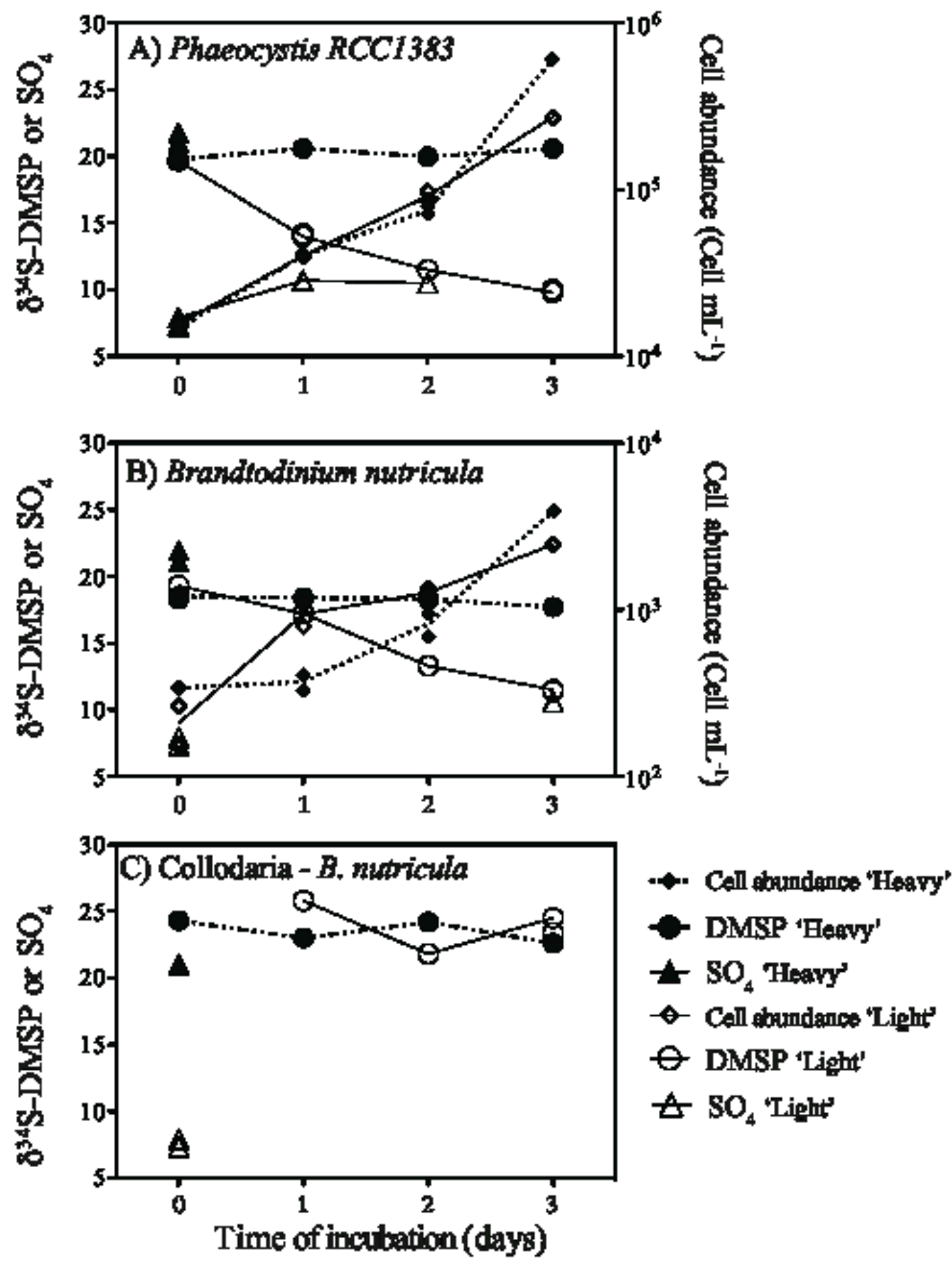


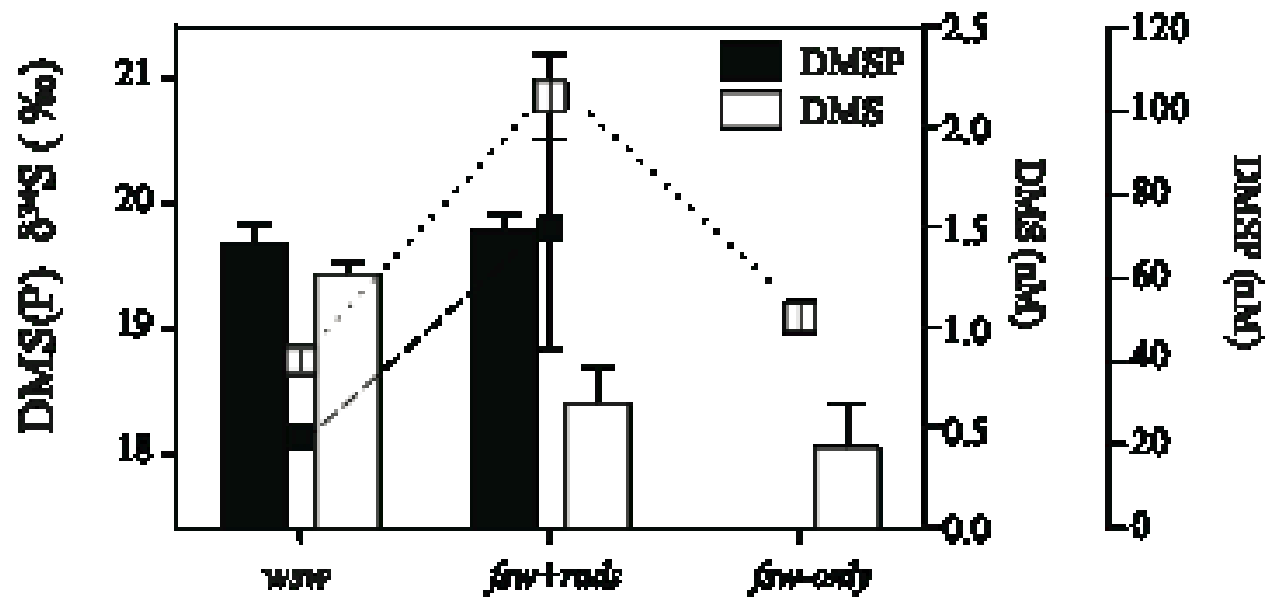

Intracellular DMSPt concentration of symbiotic microalgae as a function of growth phase and

diel cycle. The large error associated to the mean DMSPt cell content and concentration values of

cultured symbiotic microalgae (Table 1) reflected the variability associated to growth phase and photoperiod at the time of harvesting the culture. The photoperiod (day vs. night) had a significant effect on DMSP cellular concentration for B. nutricula and G. radiolariae, while this was only marginally significant for $P$. beii (two-way ANOVA, $\mathrm{p}=0.066$ ). The effect of growth phase

853 (exponential vs. stationary) on DMSPt content was only significant for G. radiolariae (two-way

854 ANOVA, $\mathrm{p}<0.0001$ ), while the interaction between both photoperiod and growth phase was

855 significant for $B$. nutricula and $P$. beii $(\mathrm{p}<0.001)$. During exponential phase, DMSP cell content was

856 slightly lower during the day than night for B. nutricula and P. beii, while the cellular DMSP

857 concentrations decreased substantially at night for these strains. In G. radiolariae DMSP content

858 decreased at night during both exponential and stationary growth phases ( $\mathrm{p}=0.003$, Supplementary 859 Figure 1). 

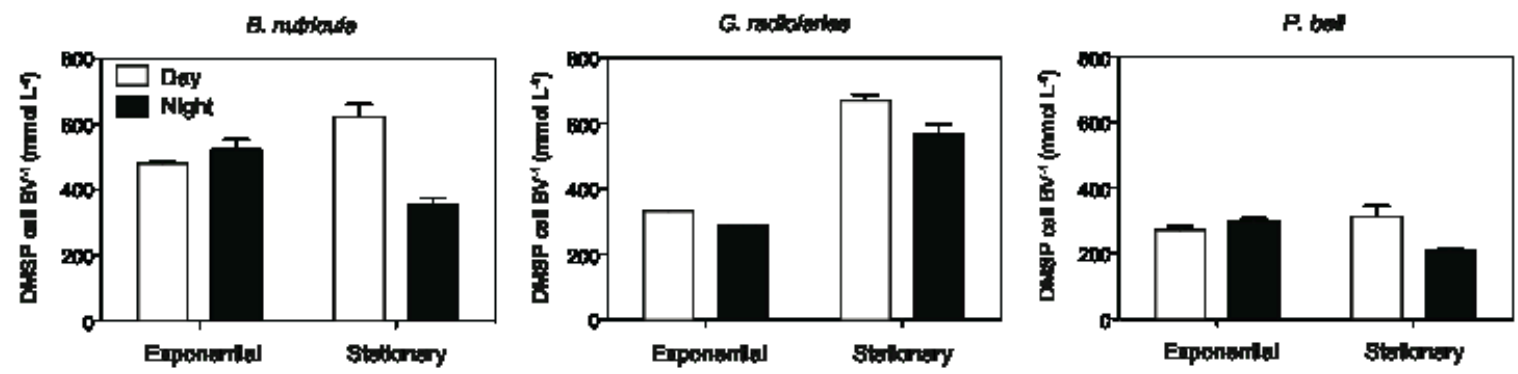

860

861 Supplementary Figure 1. Mean intracellular DMSP concentration in free-living cultures of

862 Brandtodinium nutricula (A), Gymnoxanthella radiolariae (B), and Pelagodinium bei (C) harvested at

863 different growth phases (exponential vs. stationary) and times of the daily photoperiod (day vs night).

864 Error bars represent the standard error of the mean. A) Growth $\mathrm{F}_{1,8}=0.17, \mathrm{p}=0.69$, photoperiod

$865 \mathrm{~F}_{1,8}=16.6 \mathrm{p}=0.0036$, interaction $\left.\mathrm{F}_{1,8}=32.1, \mathrm{p}=0.0005 ; \mathrm{B}\right)$ Growth $\mathrm{F}_{1,8}=304, \mathrm{p}<0.0001$, photoperiod

$866 \mathrm{~F}_{1,8}=17.7, \mathrm{p}=0.0030$, interaction $\mathrm{F}_{1,8}=2.7, \mathrm{p}=0.14 ; \mathrm{C}$ ) Growth $\mathrm{F}_{1,8}=1.4, \mathrm{p}=0.27$, photoperiod $\mathrm{F}_{1,8}=4.5$, $\mathrm{p}=0.066$, interaction $\mathrm{F}_{1,8}=12.9, \mathrm{p}=0.0071$. Two-way ANOVA not repeated measures. 